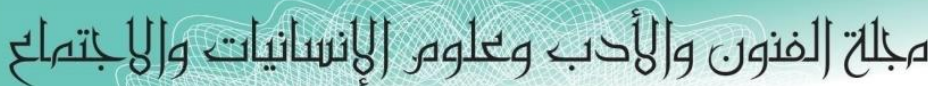

Journal of Arts, Literature, Humanities and Social Sciences

ISSN online: 2414 - 3383

ISSN print: 2616 - 3810

العدد (42) أيلول - لسبتهير 2019

\title{
برنامج تلديبي لخطوات اخذ قياسات الجسم للطالبات باستخدام جهاز مبتكر اخدات
}

\author{
د. سمر محمود عبد الغتي مقلان

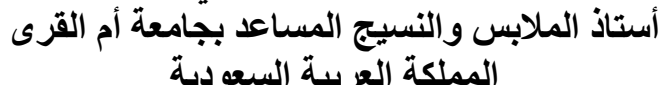

الملخص

تعتبر المقاسات من أهم معايير اختيار الملابس الجاهزة ، فنجد الفرد يهتم عند اختياره للقطعة الملبسية الجاهزة

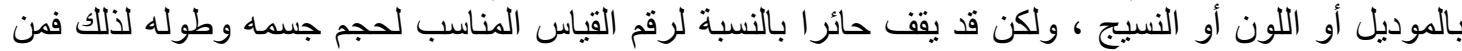

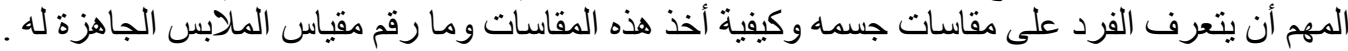

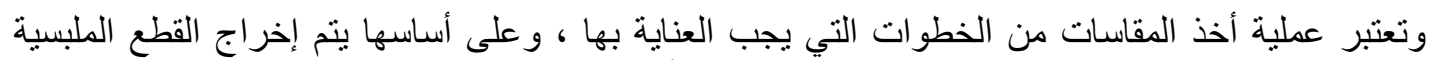
المر اد تنفيذها بدقة وتكون مطابقة لقالب الجسم ، وهي من أهم العناصر التي تساهم في نجاح عملية التفصيل التيلي التيل و الخياطة .

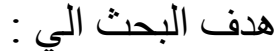

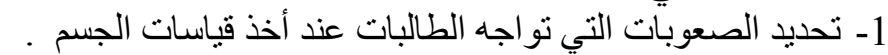

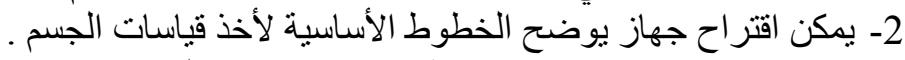

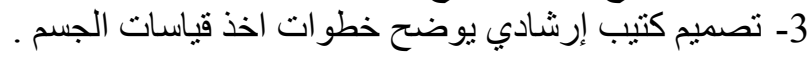

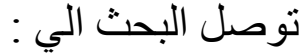

1- توجد فروق دالّة إحصائياً بين منوسطي درجات الطالبات في التطبيق القبلي والبعدي للاختبار التحصيلي

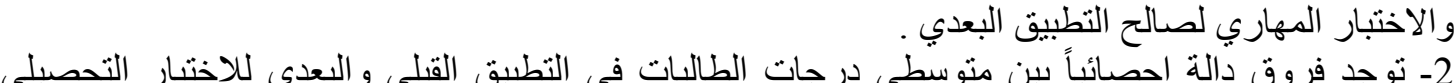

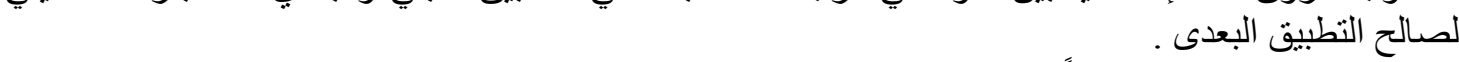
3- توجد فروق دالة إحصائياً بين منوسطي درجات الطالبات في التطبيق القبلي والبعدي للاختبار المهاري

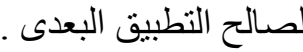

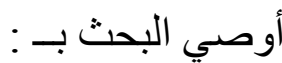
1- الاهتمام بالبحث و على ما يحتويه من معلومات في در اسة اخذ القياسات بالطريقة الصحيحة.

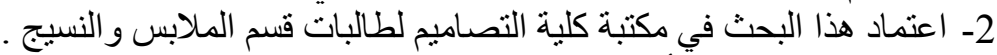
3- ضرورة اعتماد هيئة أعضاء التدريس على تدريس محتوى البحث عند اخذ القيات القياسات بالطريقة الصحيحة .

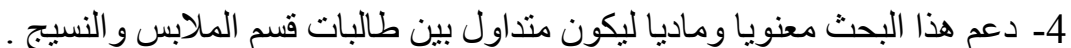
5- التعريف بهذا البحث لطالبات كلية الملابس و النسيج وكل من تهنم بتصميم الأزياء . 


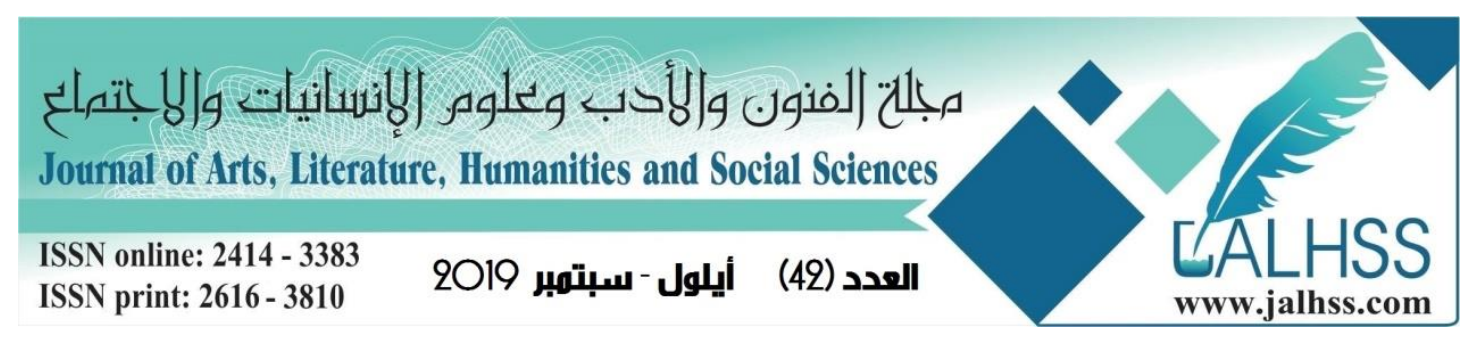

\title{
Training Program for the Steps of Taking Body Measurements for Students Using an Innovative Device
}

\begin{abstract}
Sizes are of the most important criteria for the selection of ready-made clothes, we find an individual interested in choosing a piece of clothing ready-made model, color or fabric, but may stand bewildered for the appropriate measurement number for the size of his body and length, so it is important to recognize the individual sizes of his body and how to take these sizes and number His garments.

The process of taking measurements is one of the steps that must be taken care of, and on the basis of which the pieces of clothing to be executed accurately and conform to the body template, which is one of the most important elements that contribute to the success of the process of detailing and sewing.
\end{abstract}

The research aims to:

1- Identify the difficulties faced by female students when taking body measurements.

2. A device can be suggested that shows the basic lines for taking body measurements.

3 - Design a guide book illustrating the steps to take measurements of the body.

Your search found:

1- There are statistically significant differences between the average scores of students in the pre- and post-application of achievement test and skill test in favor of post-application. 2 - There are statistically significant differences between the average scores of students in the pre- and post-application of achievement test in favor of post-application.

3 - There are statistically significant differences between the average scores of students in the pre - and post - application of the skill test in favor of the post - application.

I recommend Search by:

1 - interest in research and the information contained in the study of taking measurements in the right way.

2 - Adoption of this research in the library of the Faculty of Designs for students of the Department of Clothing and Textiles.

3- The teaching staff should rely on teaching the research content when taking the measurements in the right way.

4 - Support this research morally and materially to be circulating among the students of the Department of clothing and textile.

5 - Introducing this research to the students of the College of Clothing and Textile and anyone interested in fashion design. 


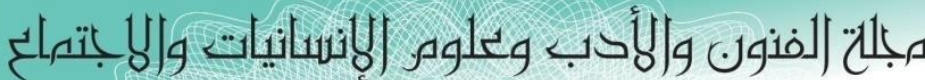

Journal of Arts, Literature, Humanities and Social Sciences

ISSN online: 2414 - 3383

ISSN print: 2616 - 3810

\section{العدد (42) أيلول - سبتهبر 2019}

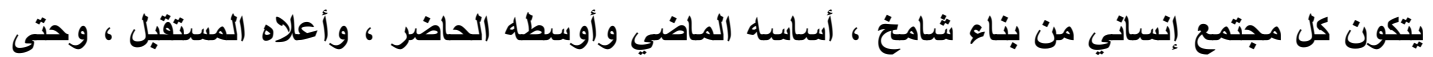

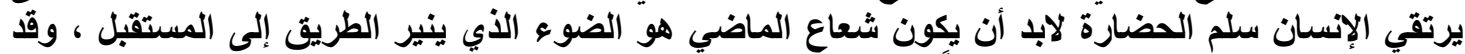

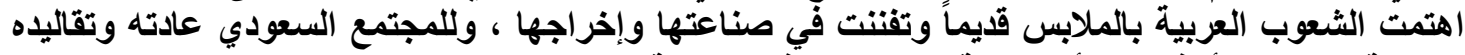

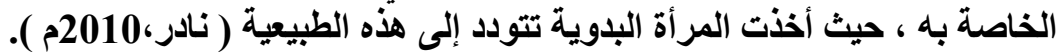

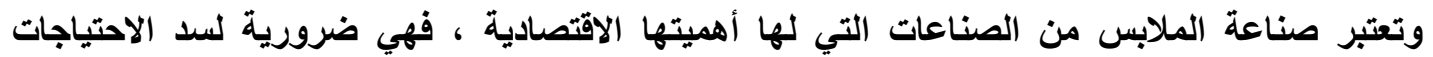

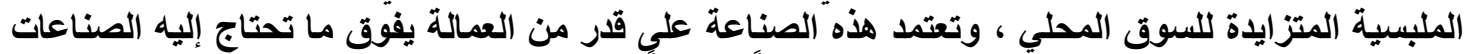

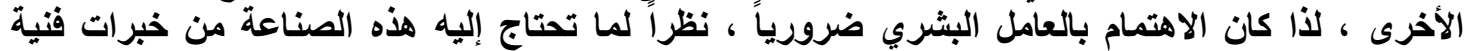

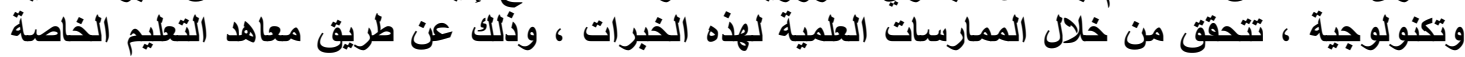

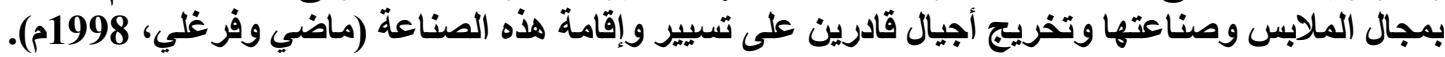

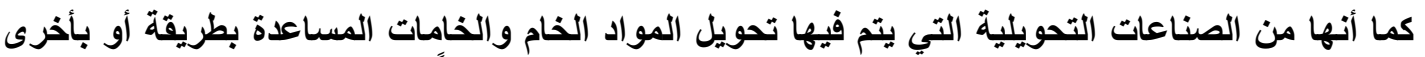

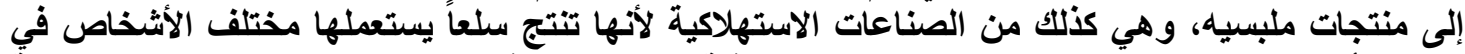

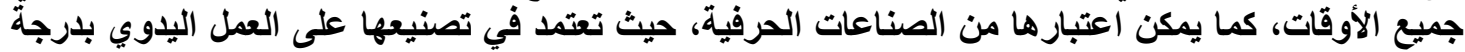

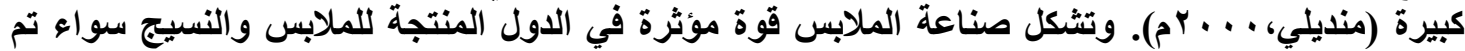

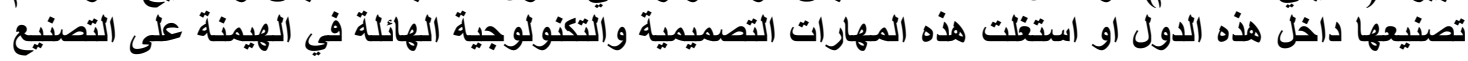

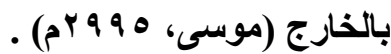

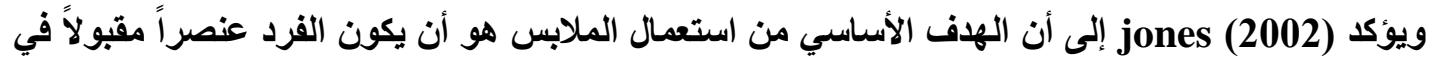

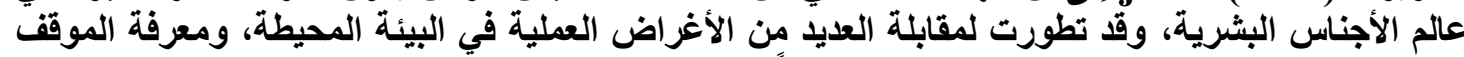

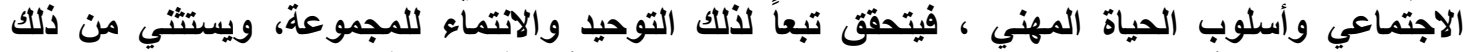

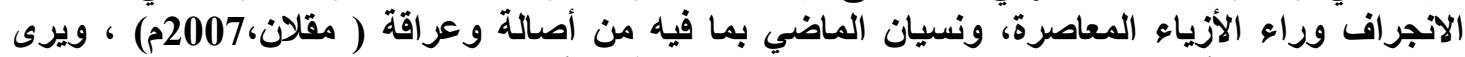

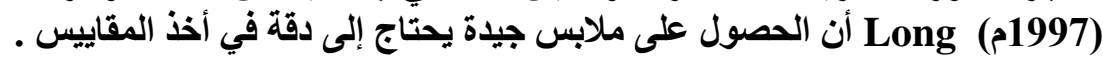

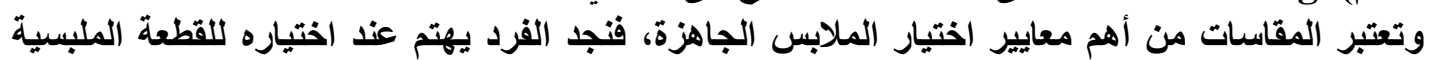

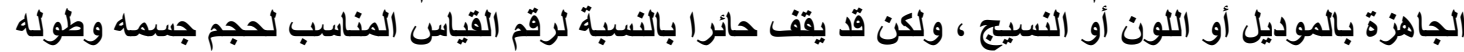

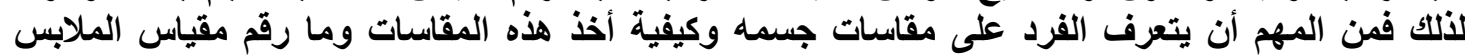

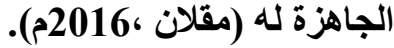

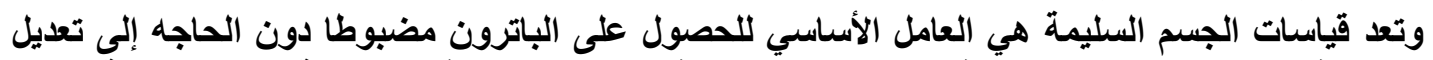

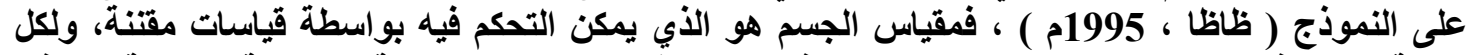

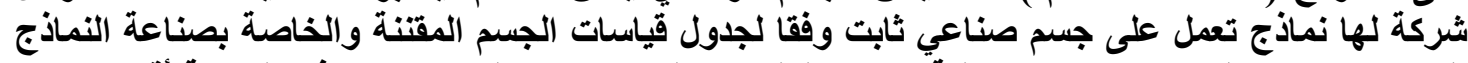

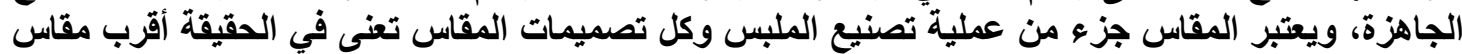
لقياسات الثخص (www.taunton.com). وتعتبر عملية أخذ المقاسات من الخطوات التي يجب العناية بها ، و وعلى أساسها يتم إخراج القطع الملبسية

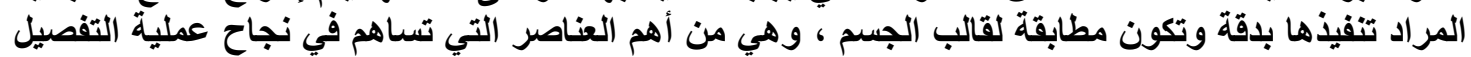
و والخياطة.

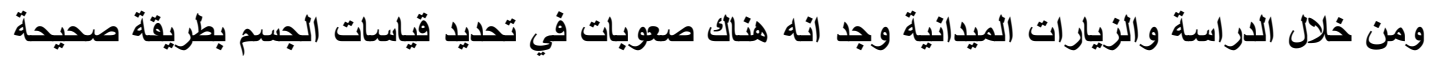

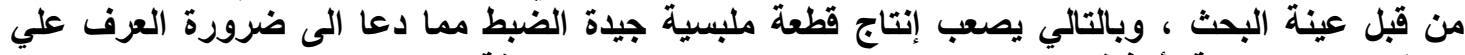

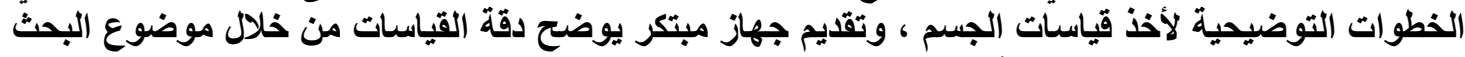
:"برنامج تدريبي لخطوات اخذ قياسات الجسم للطالبات باستخدام جهاز مبتكر".

تتلخص مشكلة البحث :

1- ما الصعوبات والمشكلات التي تواجه الطالبات لات التهالية في اخذ القياسات ؟ 


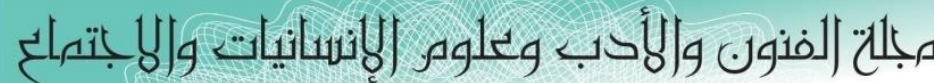

Journal of Arts, Literature, Humanities and Social Sciences

ISSN online: 2414 - 3383

ISSN print: 2616 - 3810

\section{العدد (42) أيلول - لسبتمبر 2019}

2- 2- ما أهم خطوات أخذ قياسات الجسم بطريقة مبسطة ؟

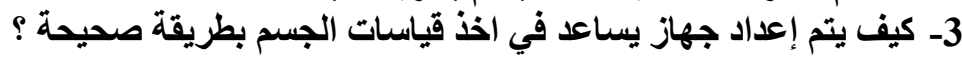
4- ما المقترح لإعداد كتيب يوضح خطوات مبسطة لأخذ قياسات الجسم ؟

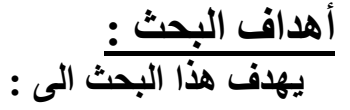

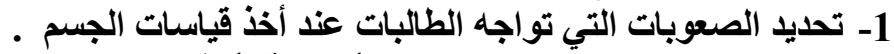

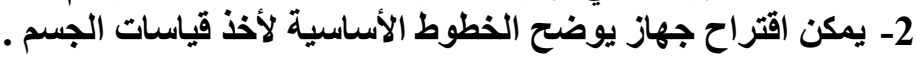

3- تصميم كتيب إرشادي يوضح خطوات بوفح اتخ اخذ قياسات الجسم .

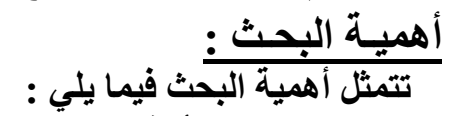

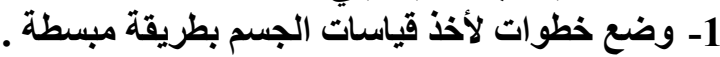

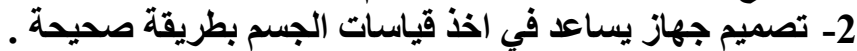

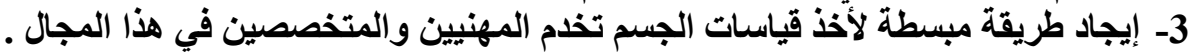

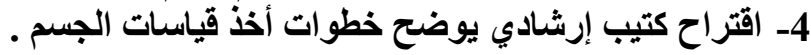

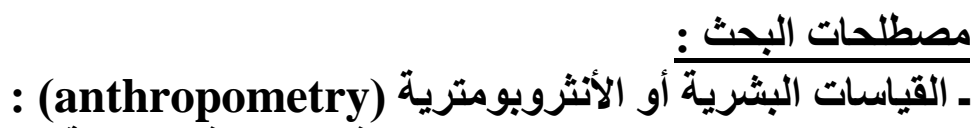

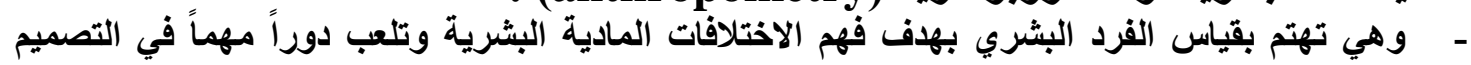

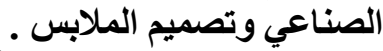
- عبارة عن إجراء قياس لأجزاء الجسم البشري وتحديد معايير لها من اجل استخدامها في غرض ما (https://ar.wikipedia.org/wiki/) ـ ش شريط القياس (المازورة) (The flat bar) :

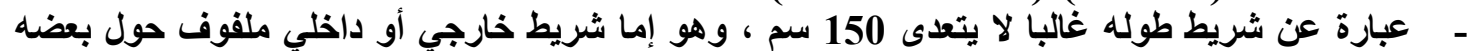

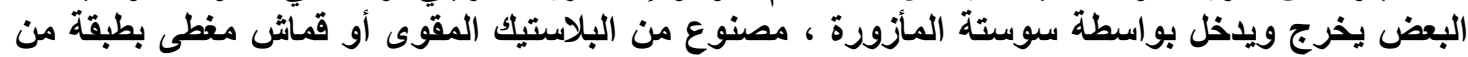

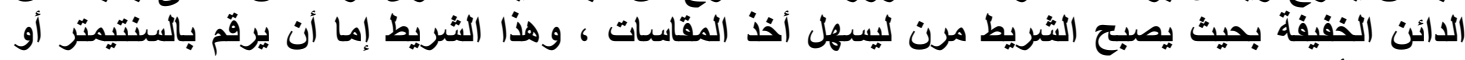

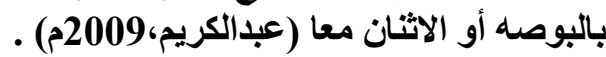

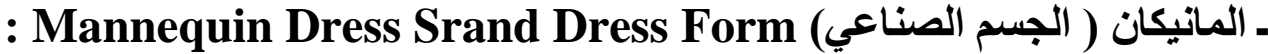

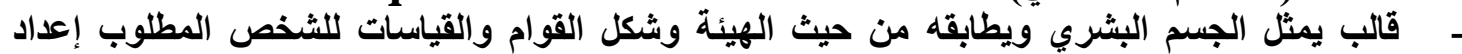

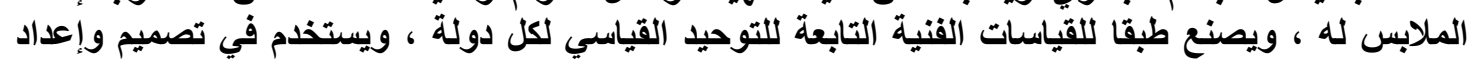

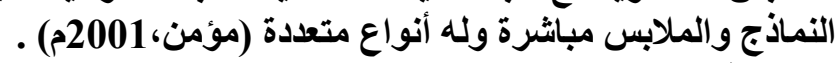

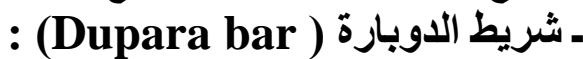

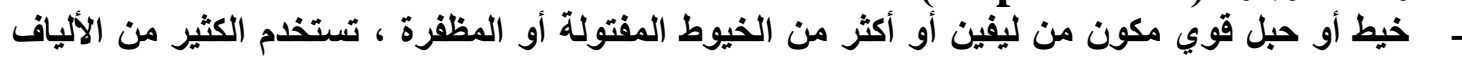

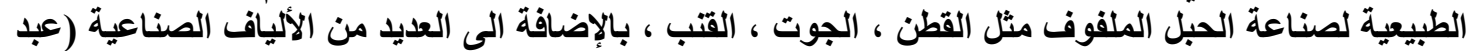

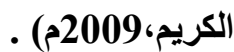

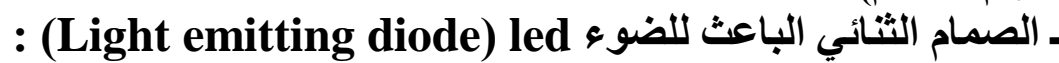
- مصدر ضوئي مصنوع من مواد وأثباه الموصلات ، تبعث الضوء حينما يمر خلاله تيار كهربائي ، ويكثر

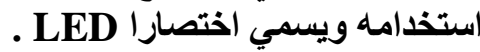
(https://ar.mWikipedia.org/Wiki/) فروض البوثث :

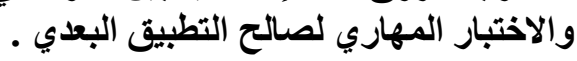


مبلحة لفنون والأدب وعلوه الإنسانيات و|لابتهماع

Journal of Arts, Literature, Humanities and Social Sciences

ISSN online: 2414 - 3383

ISSN print: 2616 - 3810

\section{العدد (42) أيلول - سبتمبر 2019}

2- توجد فروق دالة إحصائياً بين متوسطي درجات الطالبات في التطبيق القبلي والبعدي للاختبار التحصيلي

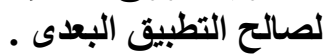
3- توجد فروق دالة إحصائياً بين متوسطي درجات الطالبات في التطبيق القبلي والبعدي للاختبار المهاري

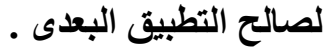

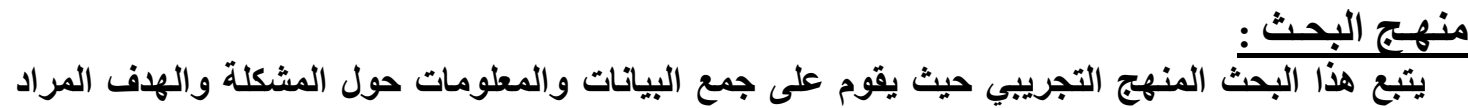

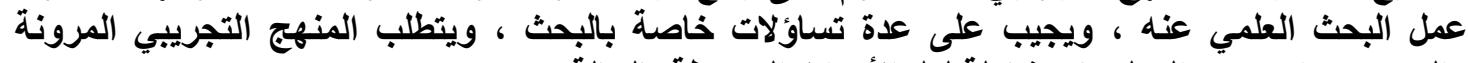
والوضوح وإن تكون المعلومات شاملة لكل الأحداث المرتبطة بأل بالحالة .

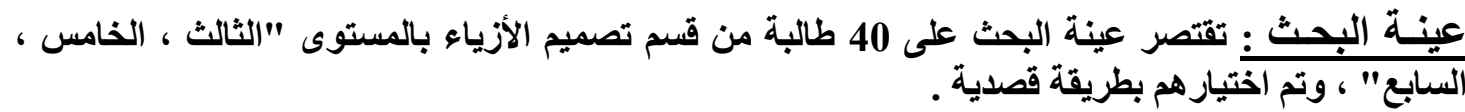

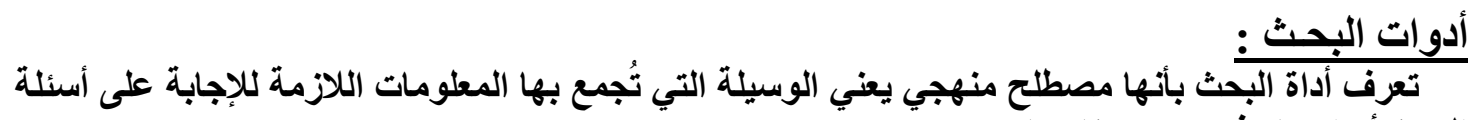

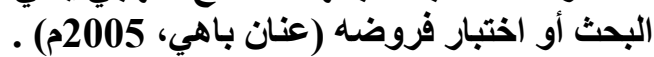

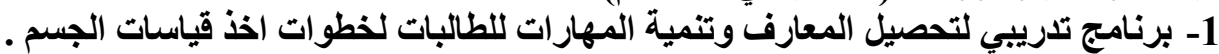

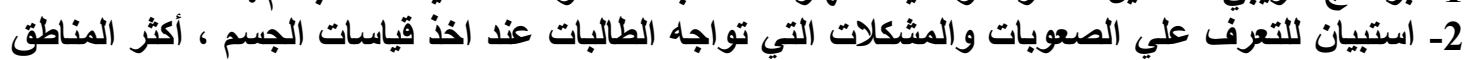
صعوبة في اخذ قياسها ، مقترحات لحئ الصل المشكلة .

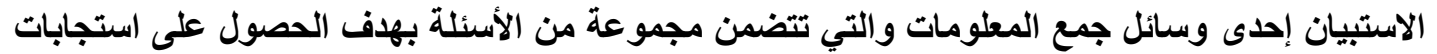

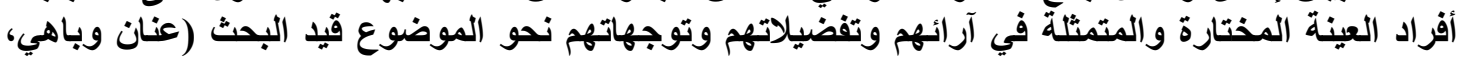

3- اختبار تحصيلي (قبلي / بعدي) لقياس المعارف المتضمنة في البرنامج التدريبي .

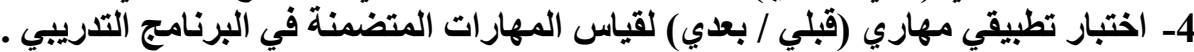

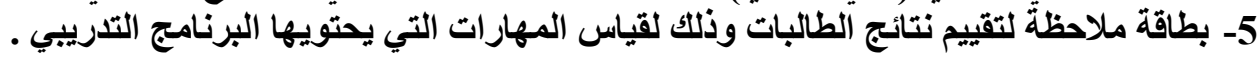

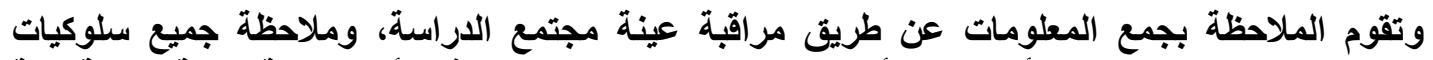

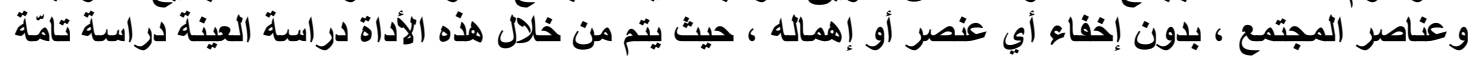

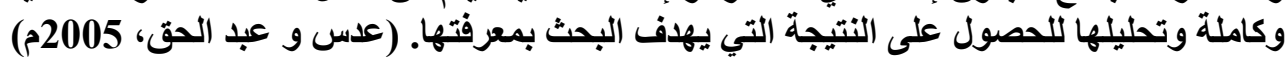

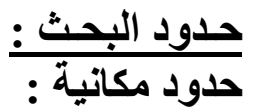

$$
\begin{aligned}
& \text { • جامعة أم القرى، كلية التصاميم "قسم تصميم الأزياء". }
\end{aligned}
$$

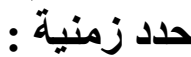

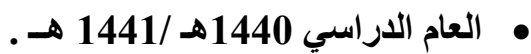

$$
\begin{aligned}
& \text { أنماط الجطار النظري: }
\end{aligned}
$$

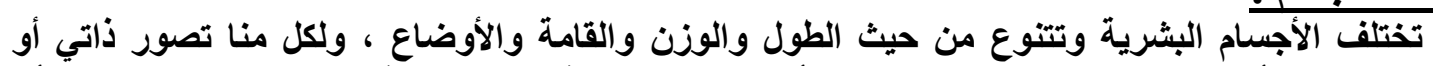

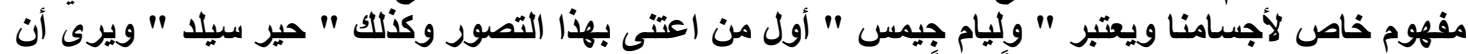

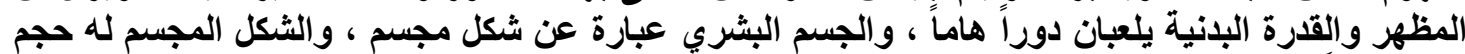

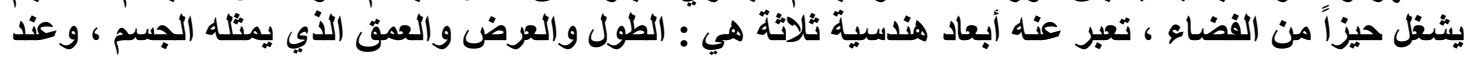

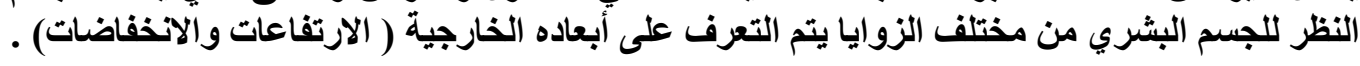

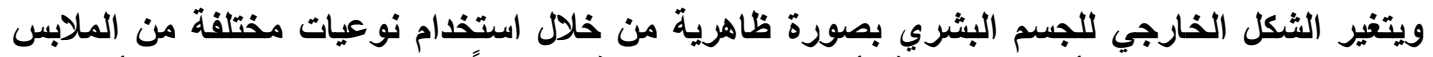

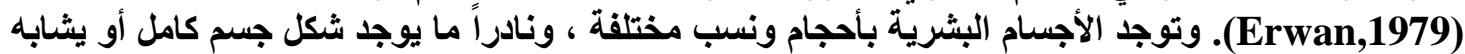
شكل جسم آخر (مؤمن والزفتاوي وعبود، 2003م). ولقد اهتمت كثير من المؤسسات المتخصصة ونئ في النماذج 


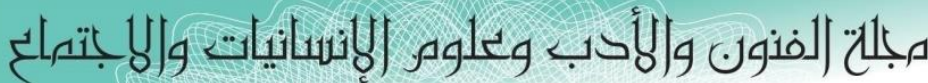

Journal of Arts, Literature, Humanities and Social Sciences

ISSN online: 2414 - 3383

ISSN print: 2616 - 3810

\section{العدد (42) أيلول - سبتهبر 2019}

بدراسة الجسم البشري للمرأة للوصول إلى قياسات وتقسيمات نموذجية تتفق مع معظم أنماط الأجسام ، وقد

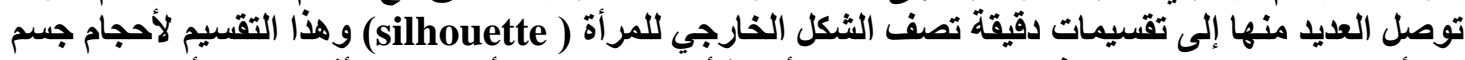

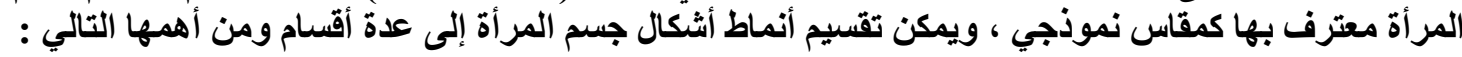

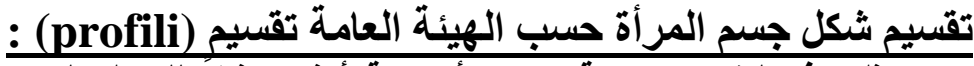

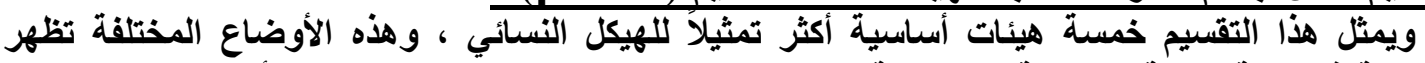

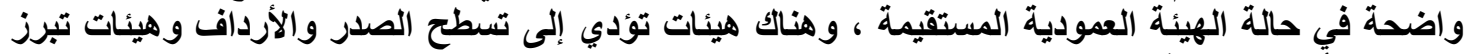

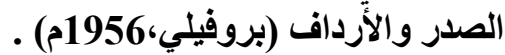

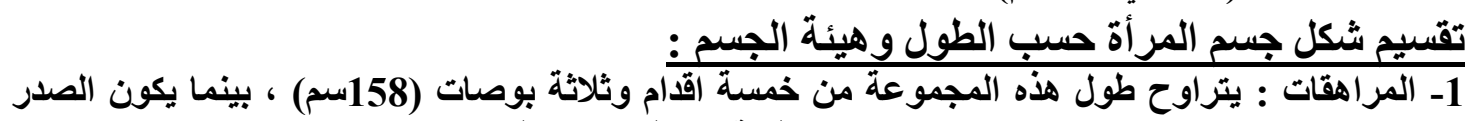

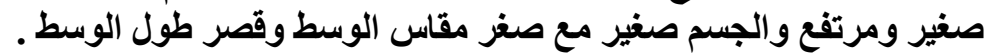

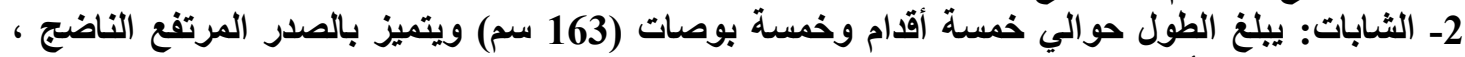

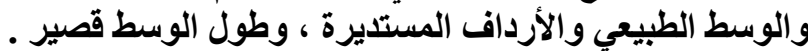

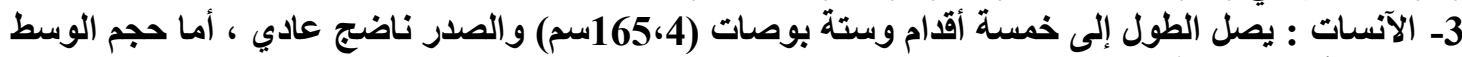

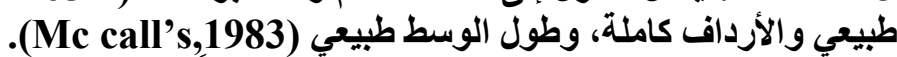
4- السيدات : الطول خمسة أقدام وستة بوصات الوسئ أيضاً (165،4سم) والصدر يكون كامل النمو ومنخفضا ، محيط

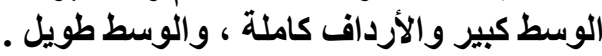

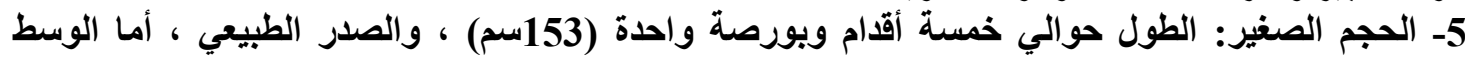

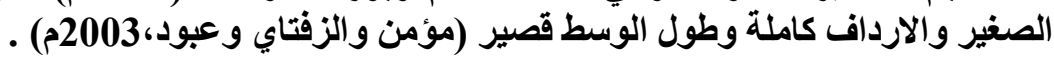

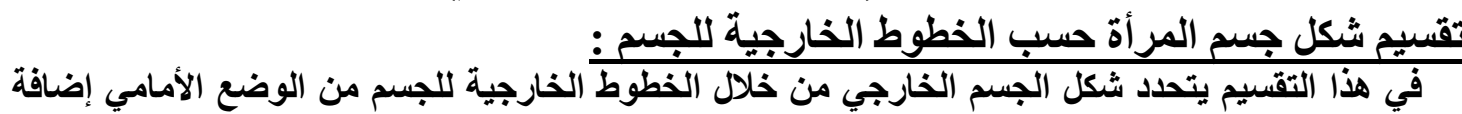

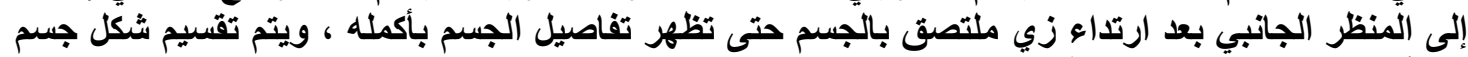

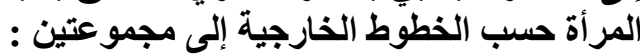

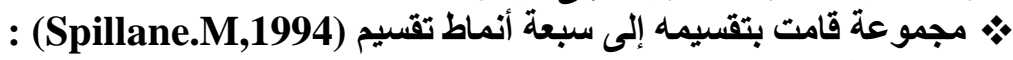

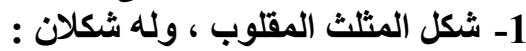

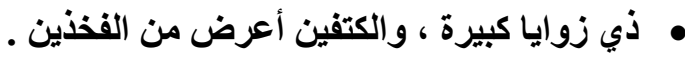
• الجزء العلوي ثقيل والكتفين عريضين ، والصدر أكبر من الفخذين ، ولكن الصدر والفخذين مستويان وليس منحنيان.

$$
\text { 2- الشكل المستقيم (الأنبوبي) : }
$$

يلاحظ في هذا الثكل استقامة الكتفين مع الفخذين إلى درجة كبيرة ، ويقل الخصر (الوسط) عن الفخذين

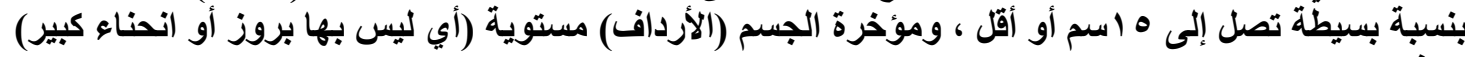
و وهذا الجسم منه الممتلئ ومنه النحيل.

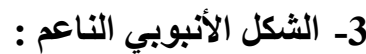

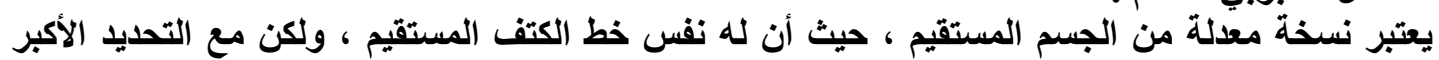

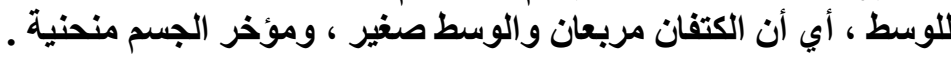

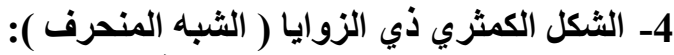

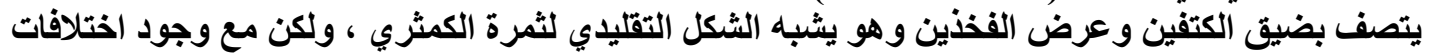

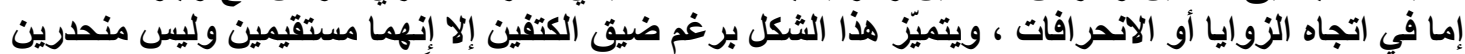

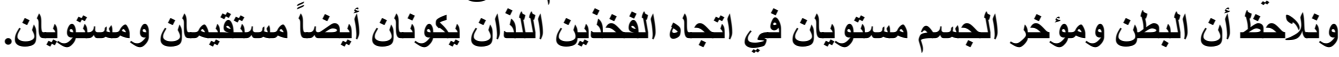

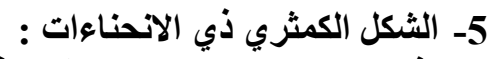

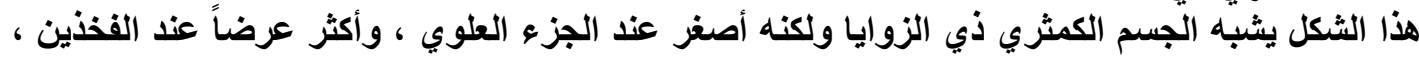
والمظهر الجانبي أكثر انحناءً والكتفين منحدرات والفخذين منحنيان ، ومؤخرة الجسم مستديرة . 
مبلحة لفنون والأدب وعلوه الإنسانيات و|لبابتهاع

Journal of Arts, Literature, Humanities and Social Sciences

ISSN online: 2414 - 3383

ISSN print: 2616 - 3810

\section{العدد (42) أيلول - لسبتهبر 2019}

6- شكل الساعة الزجاجية ( الناقوس ):

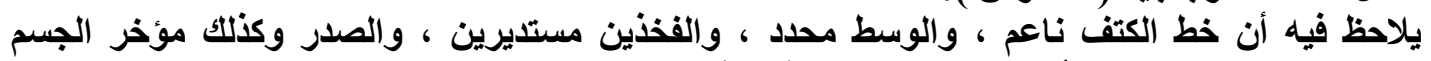

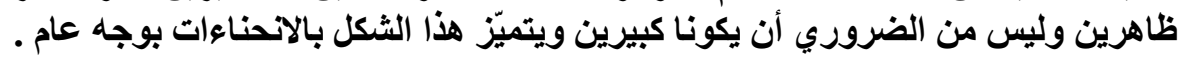
7- 1 - شكل الجسم المستدير:

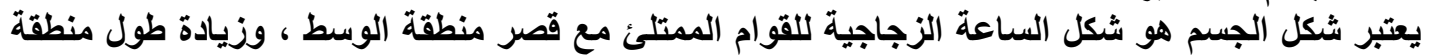

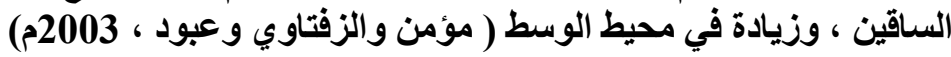

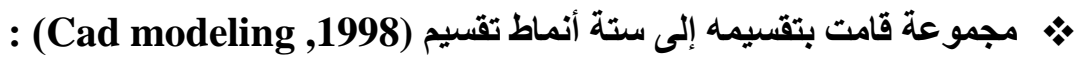

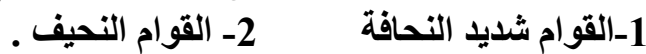

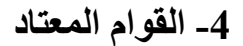
6- القوام شديد الامتلاء ( مؤمن.الزفتاوي.عبود ، 2003م).

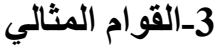

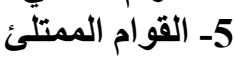

ضبط الملابس لمقاستات الجسم :

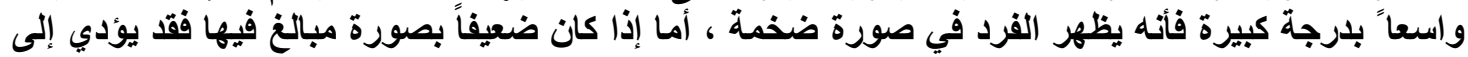

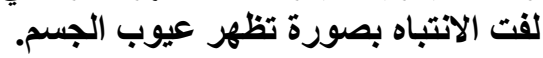

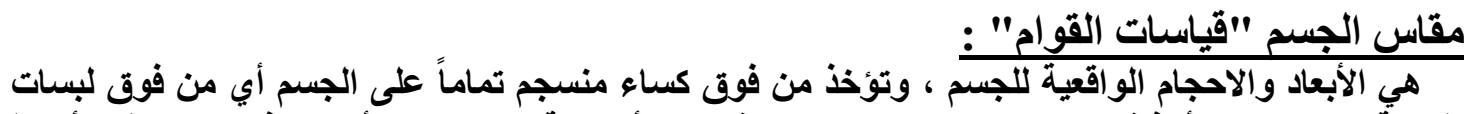

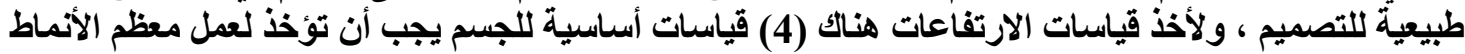

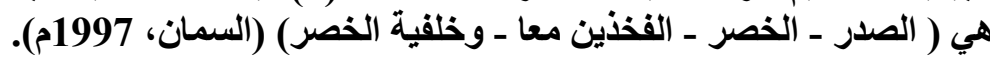

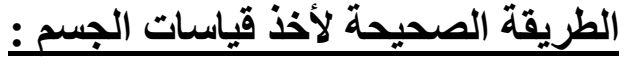

جدول (1) يوضح طريقة أخذ القياسات

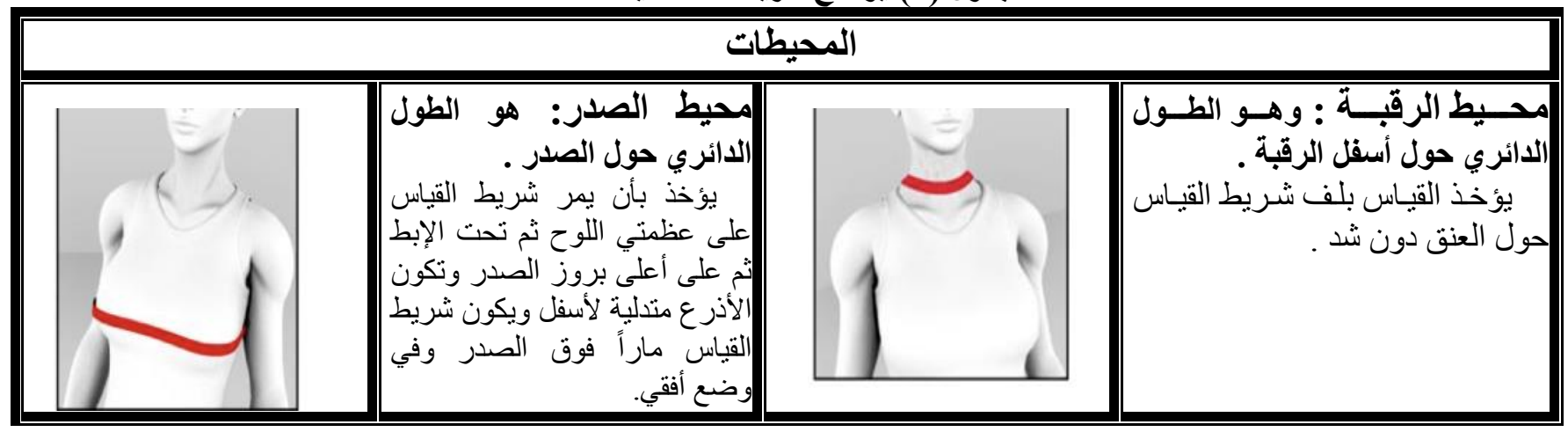




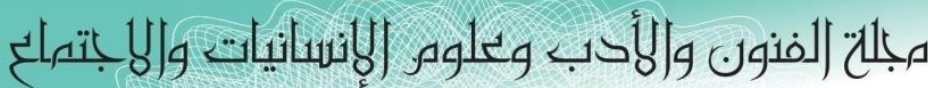
Journal of Arts, Literature, Humanities and Social Sciences

ISSN online: 2414 - 3383

ISSN print: 2616 - 3810

\section{العدد (42) أيلول - سبتمبر 2019}

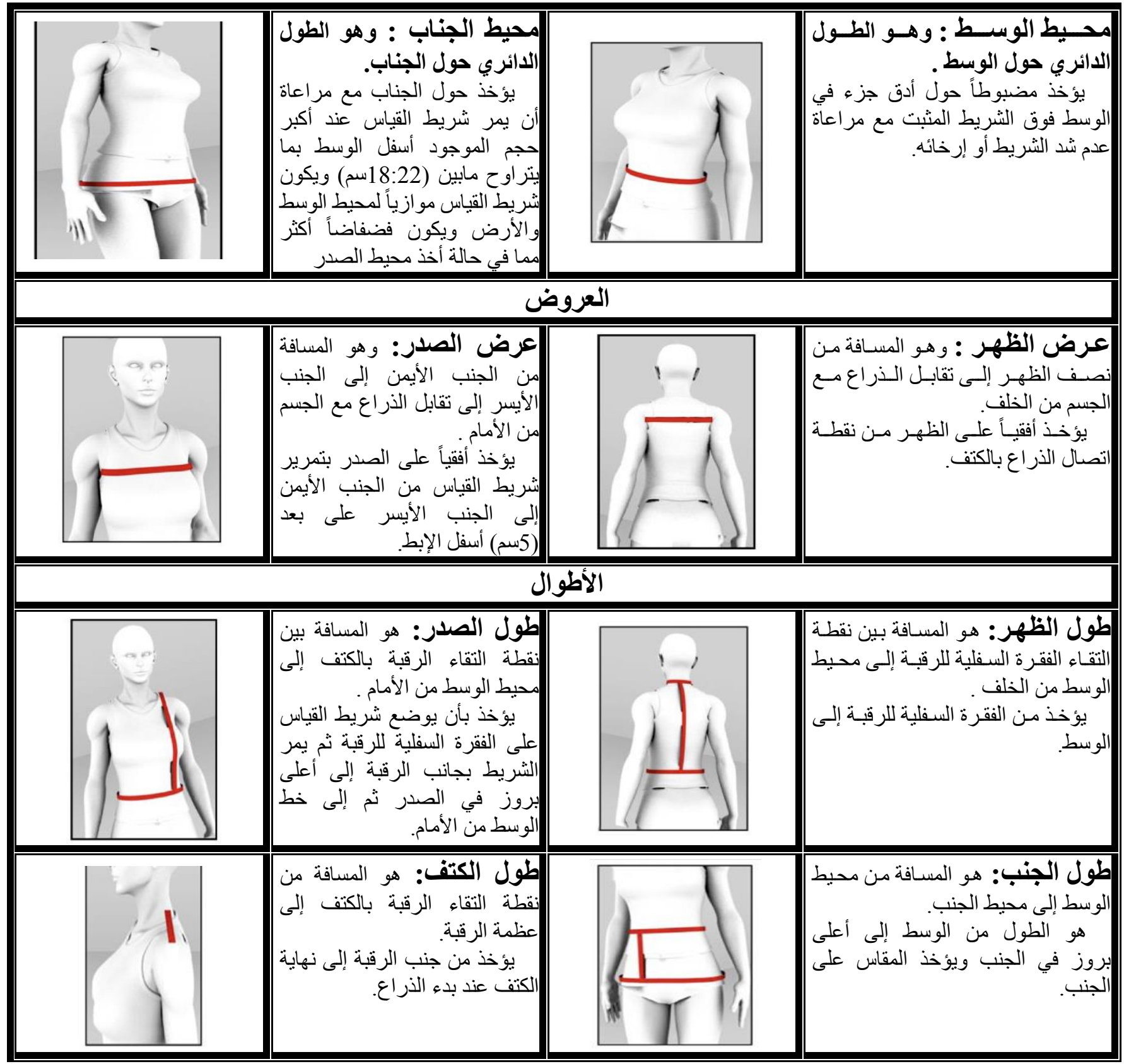




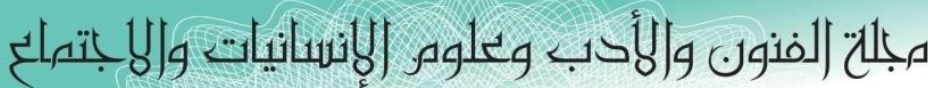
Journal of Arts, Literature, Humanities and Social Sciences

ISSN online: 2414 - 3383

ISSN print: 2616 - 3810 العدد (42) أيلول - سبتمبر 2019

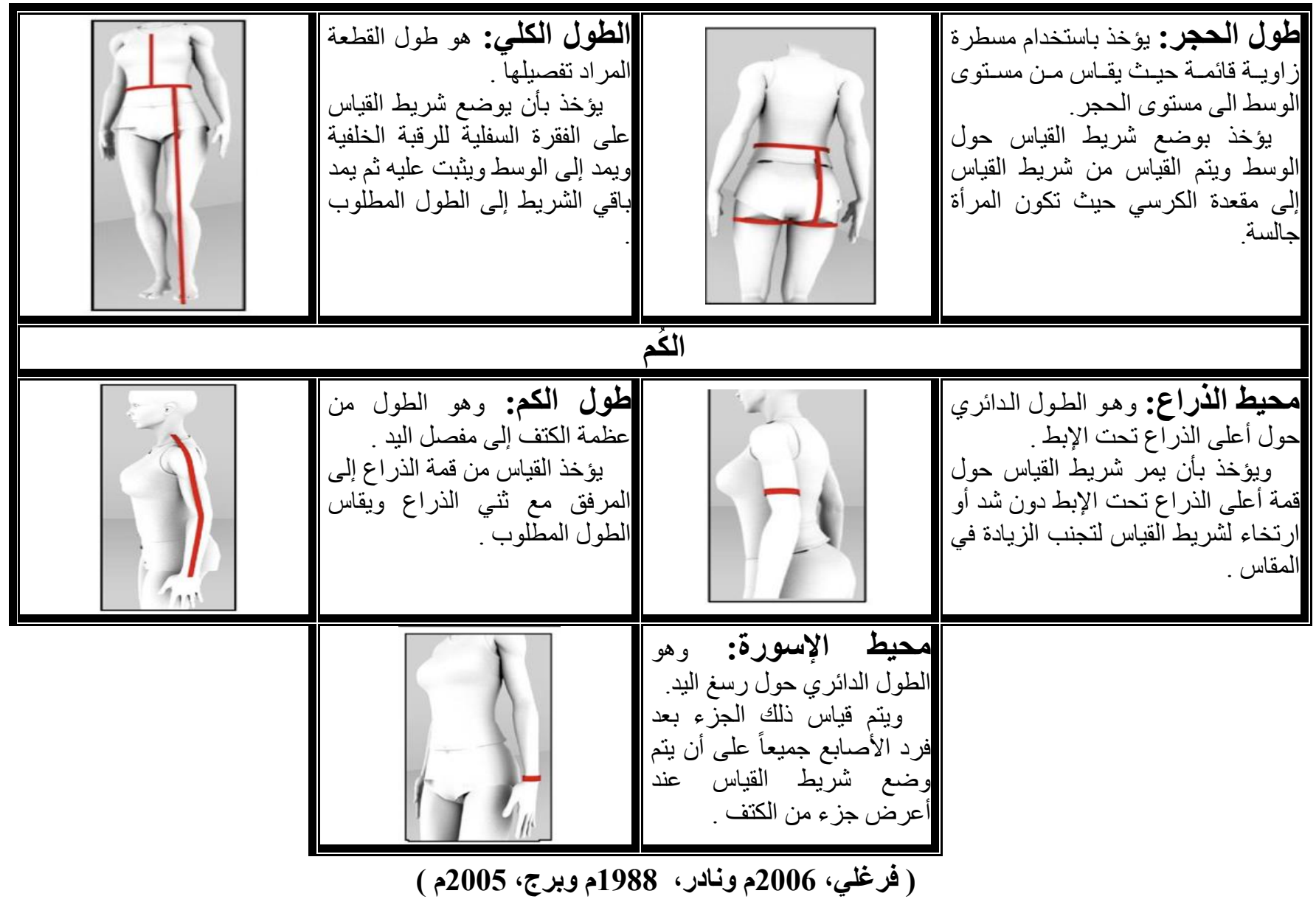

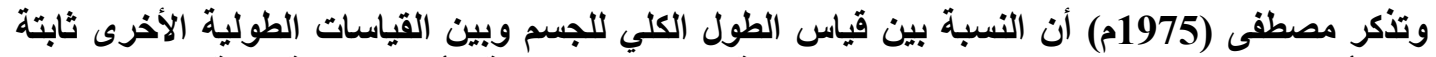

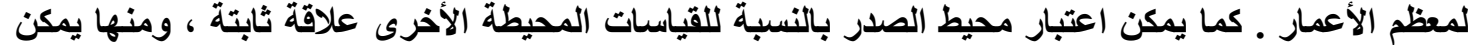

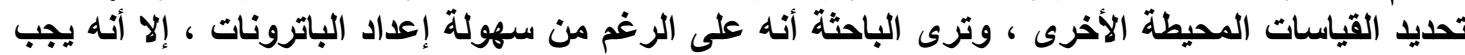

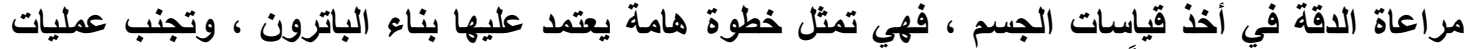

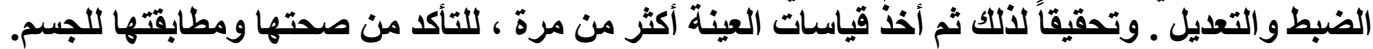

تهذف الاراسةّة التطبيقية إلى ابتكار جهاز يساعد في أخذ قياسات الجسم بلدقه ، بالإضافة إلى عمل مانيكان

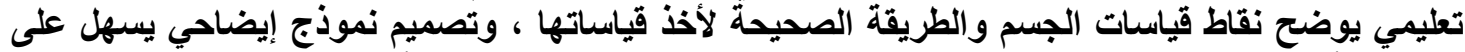

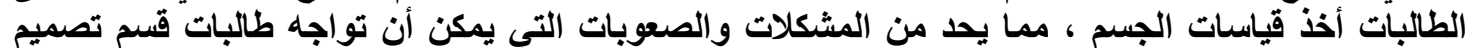

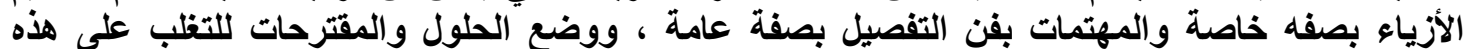

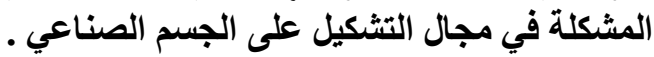


مبلحت (لفنون والأدب وعلوهر الإنسانيات والبانتهاع Journal of Arts, Literature, Humanities and Social Sciences

ISSN online: 2414 - 3383

ISSN print: 2616 - 3810

\section{العدد (42) أيلول - سبتمبر 2019}

الأدوات المستخدمة في الاراسة التطبيقية :

جدول (2) يوضح الأدوات المستخدمة في الدراسة التطبيقية

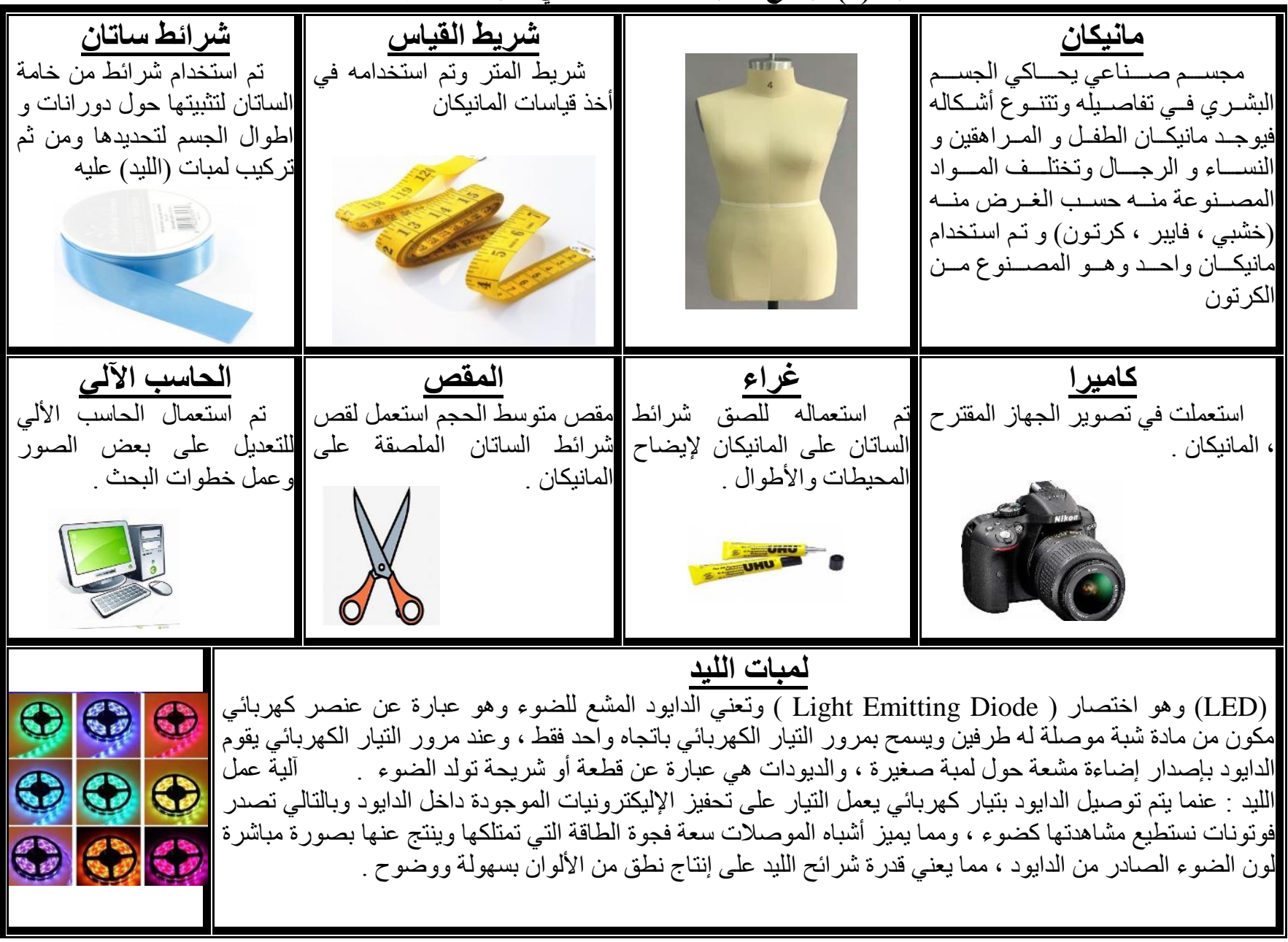

$$
\text { |قتراح مانيكان تعليمى : }
$$

جدول (3) يوضح الأدوات المستخدمة في إعداد الوسيلة التوضيحية

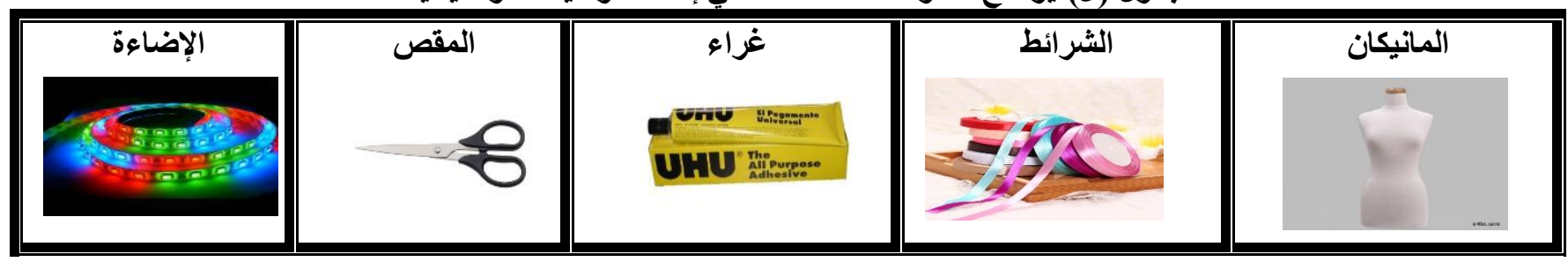


مبلح" (لفنون والأدب وعلوه البانسانيات و|لهاتهماع Journal of Arts, Literature, Humanities and Social Sciences

ISSN online: 2414 - 3383

ISSN print: 2616 - 3810

العدد (42) أيلول - سبتمبر 2019

\section{قياسات الجسم على المانيكان المقترح : \\ الخطوة الأولى : تجهيز المانيكان اليكان المئرع}

جدول (4) يوضت تجهيز الماتيكان

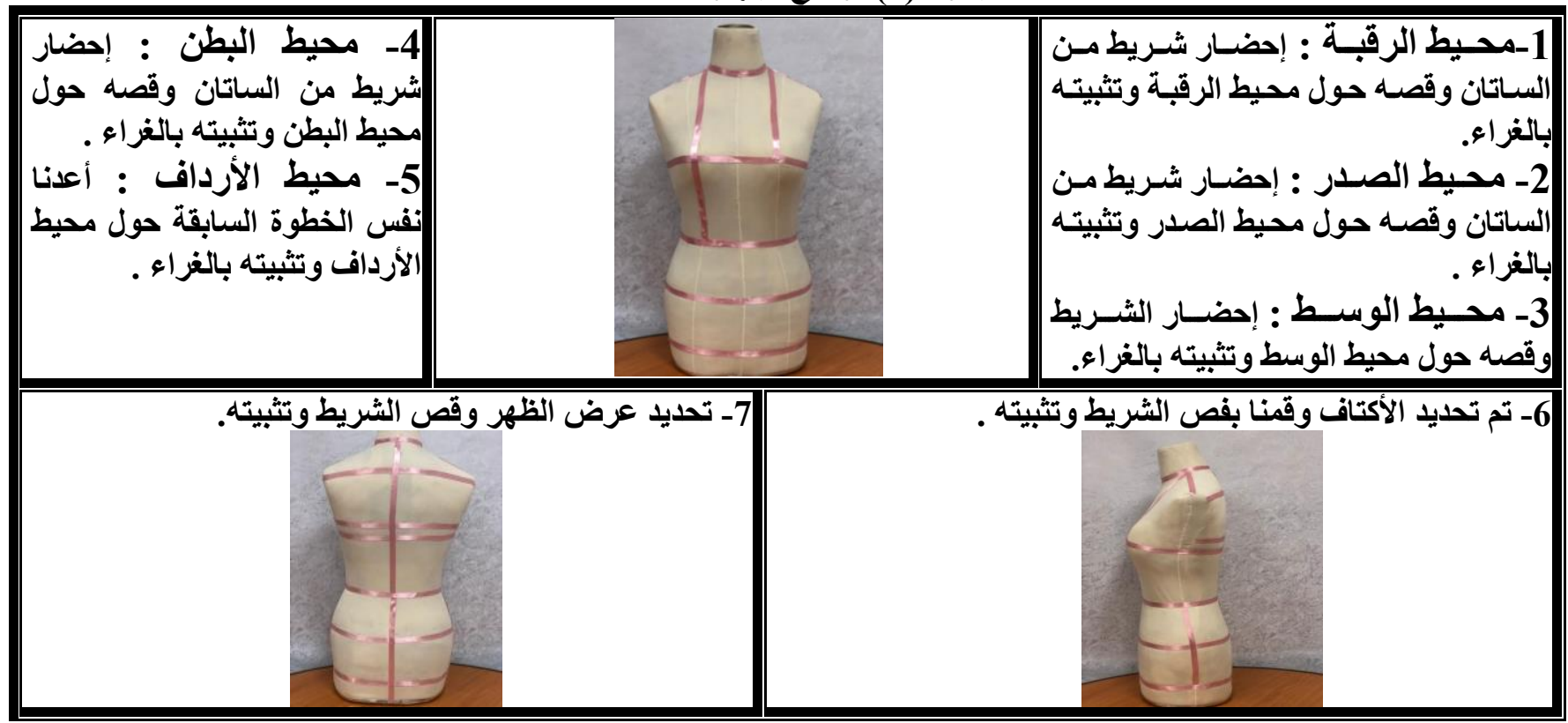

الخطوة الثانية : أخذ أطوال المانيكان :

جدول (5) يوضح أطو ال المانيكان

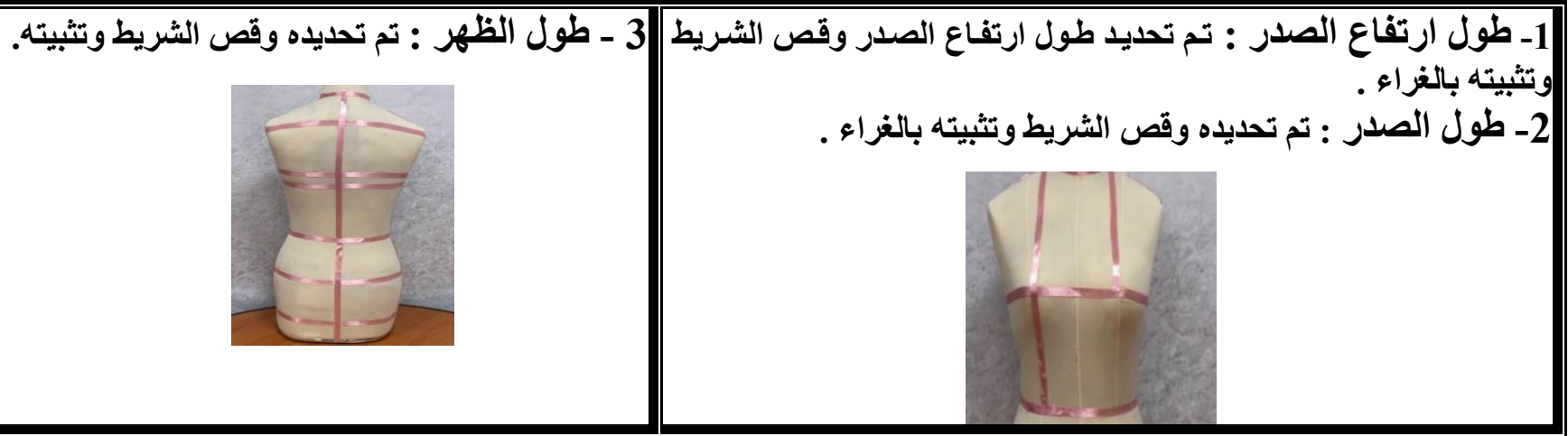


مبلح (لفنون والأدب وعلوه الانسانيات و|لبانتماع| Journal of Arts, Literature, Humanities and Social Sciences

ISSN online: 2414 - 3383

ISSN print: 2616 - 3810 العدد (42) أيلول - سبتهمر 2019

الخطوة الثالثة : المانيكان المقتر

جدول (5) يوضح المانيكان المقترح

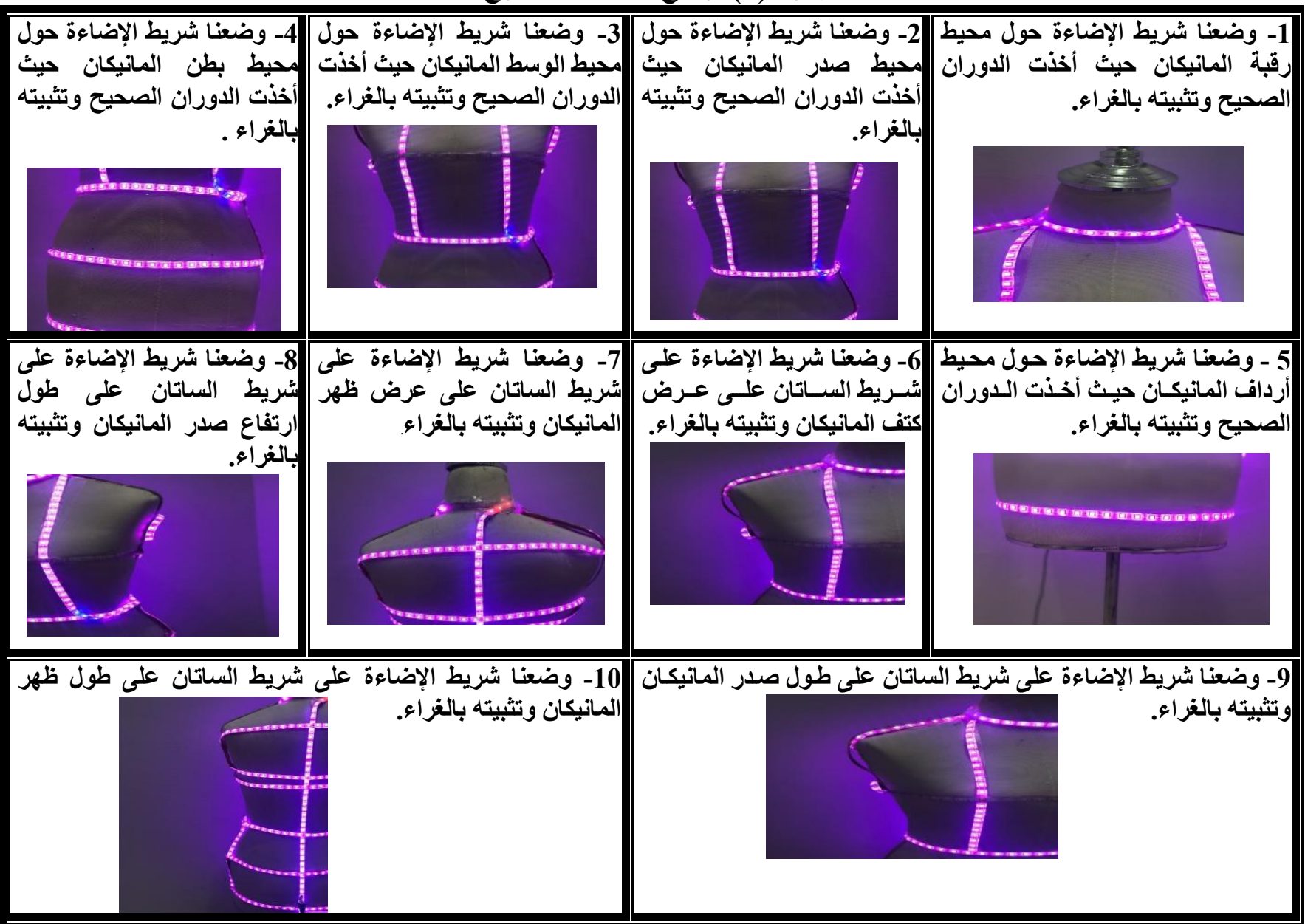

الجهاز المقترح لقياسات الجسم :

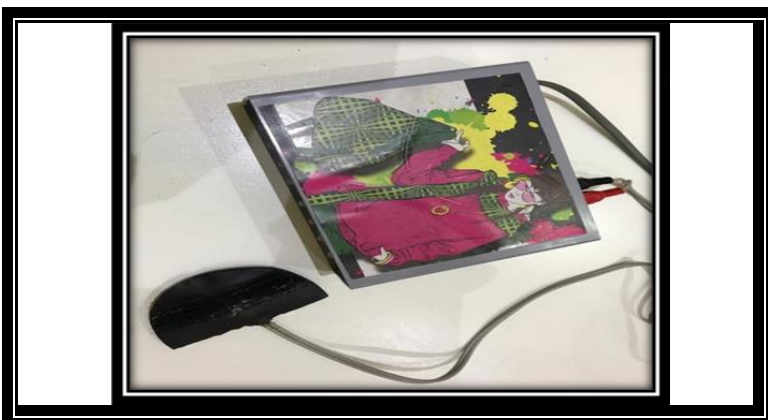

شكل (1) يوضح شكل الجهاز 
مبلح" لفنونه والأدب وعلوه الإنسانيات و|لهاتهماع Journal of Arts, Literature, Humanities and Social Sciences

ISSN online: 2414 - 3383

ISSN print: 2616 - 3810

العدد (42) أيلول - سبتهبر 2019

LALHSS

www.jalhss.com

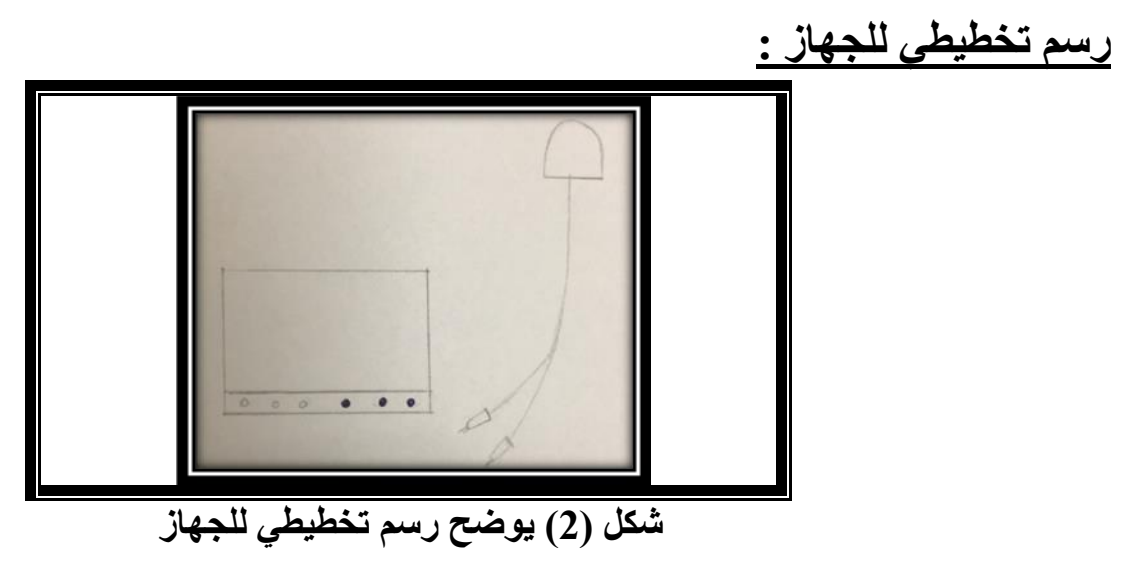

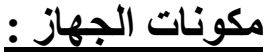

جدول (6) يوضح مكونات الجهاز

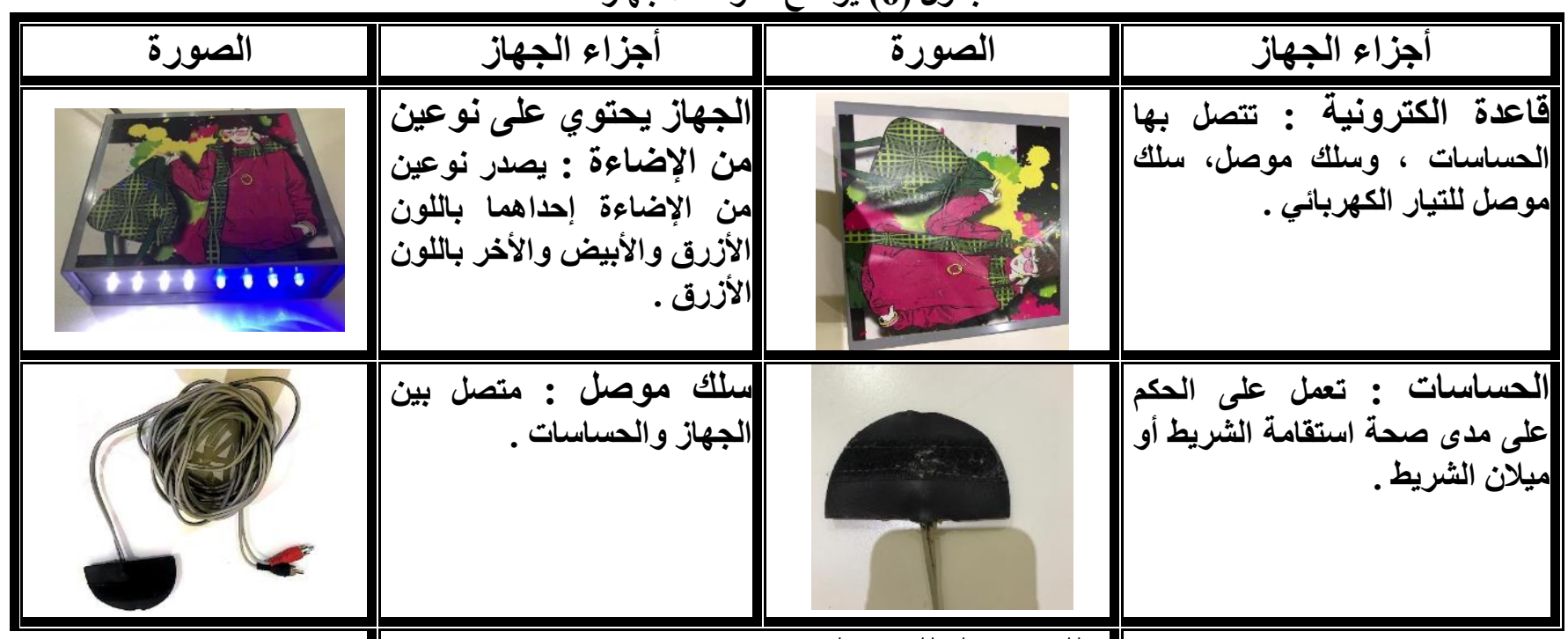

سلتك موصل للتيار الكهربائي : متصل بين الجهاز والتيار||

الكهربائي موصل.

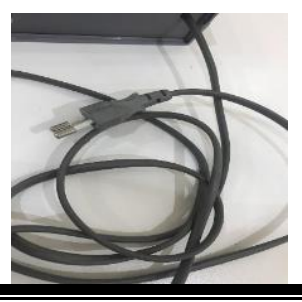

طريقة عمل الجهاز :

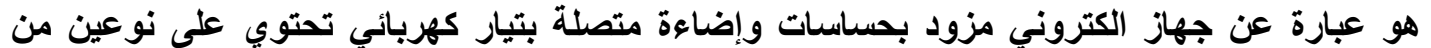
الإضاءة إحالها باللون الأزرق والأبيض والأخر باللون الأزرق عند وضع الجهاز بالطريقة الصحيحة بحيث 


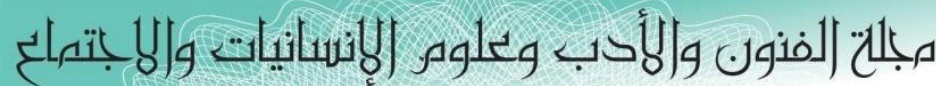

Journal of Arts, Literature, Humanities and Social Sciences

ISSN online: 2414 - 3383

ISSN print: 2616 - 3810

\section{العدد (42) أيلول - سبتمبر 2019}

تكون الحساسات عند التقاء شريط القياس يضئ باللون الأزرق والأبيض ، وفي حالة ميلان شريط القياس عن

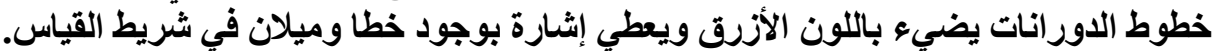

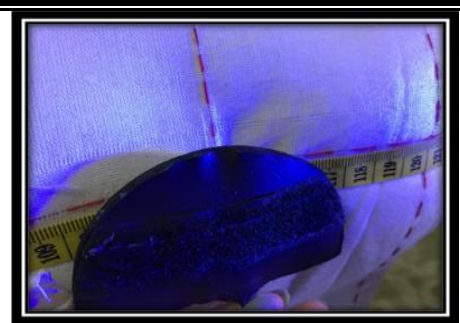

شكل (4) توضيح صورة للماتيكان والجهاز معاً

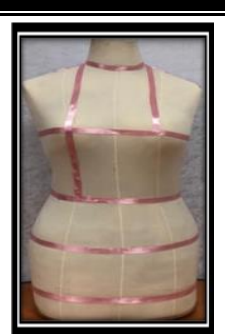

شكل (3) توضيح صورة لتجهيز المانيكان

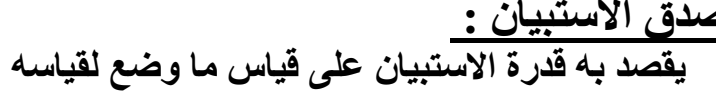

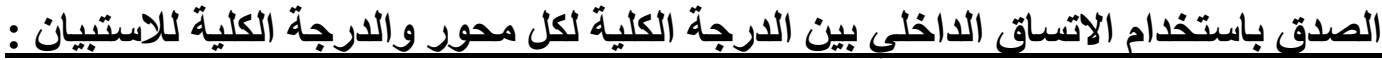

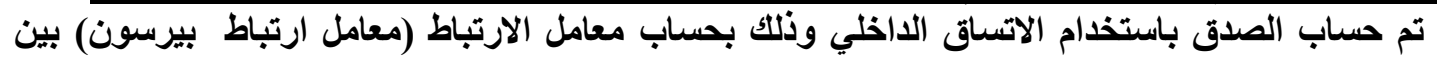

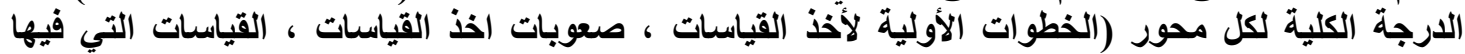

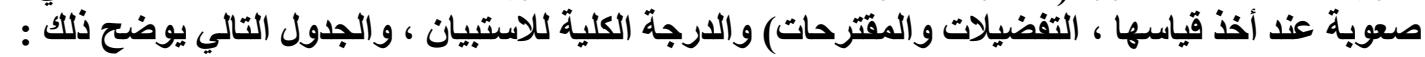

جدول (7) قيم معاملات الارتباط بين درجة كل محور ودرجة الاستبيان

\begin{tabular}{|c|c|c|}
\hline 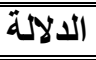 & الارتباط & \\
\hline 0.01 & 0.761 & المحور الأول : الخطوات الأولية لأخذ القياسات \\
\hline 0.01 & 0.925 & المحور الثاني : صعوبات اخذ القياسات \\
\hline 0.01 & 0.823 & المحور الثالث : القياسات التي فيها صعوبة عند أخذ قياسها \\
\hline 0.01 & $\mathbf{0 . 8 7 7}$ & المحور الرابع : التفضيلات والمقترحات \\
\hline
\end{tabular}

يتضح من الجدول أن معاملات الارتباط كلها دالة عند مستوى (0.01) لاقترابها من الواحد الصحيح مما

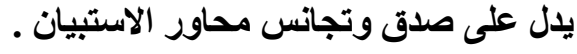
الثباث : الثل: يقصد بالثبات reability دقة الاختبار في القياس والملاحظة ، و وعدم تناقضه مع نفسه ، و واتساقه و واطر اده

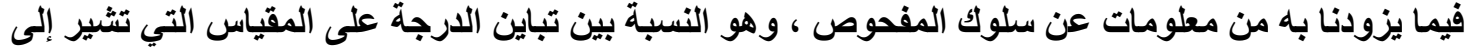

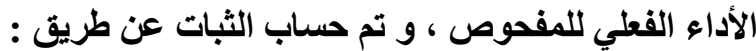

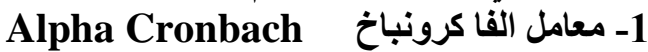

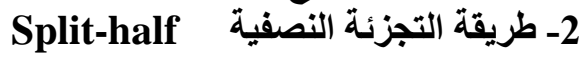
جدول (8) قيم معامل الثبات لمحاور الاستبيان

\begin{tabular}{|c|c|c|}
\hline التجزئة النصفية & معامل الفا & المحاور \\
\hline $0.845-0.769$ & $\mathbf{0 . 8 0 7}$ & المحور الأول : الخطوات الأولية لأخذ القياسات \\
\hline $0.784-0.702$ & 0.744 & المحور الثاني : صعوبات اخذ القياسات \\
\hline $0.958-0.873$ & 0.911 & المحور الثالث : القياسات التي فيها صعوبة عند أخذ قياسها \\
\hline $0.826-0.740$ & 0.789 & المحور الرابع : التفضيلات والمقترحات \\
\hline $0.890-0.817$ & $\mathbf{0 . 8 5 5}$ & ثبات الاستبيان ككل \\
\hline
\end{tabular}


مبلحة لفنون والأدب وعلوه الإنسانيات و|لبابتهاع

Journal of Arts, Literature, Humanities and Social Sciences

ISSN online: 2414 - 3383

ISSN print: 2616 - 3810

العدد (42) ايلول -سبتهبر 2019

يتضح من الجدول السابق أن جميع قيم معاملات الثبات : معامل الفا ، التجزئة النصفية ، دالة عند مستوى

0.01

صدق وثبات الاختبار التحصيلى : الانئي

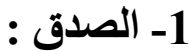

يتطق موضوع صدق الاختبار بما يقيسه الاختبار و إلى أي حد ينجح في قياسه .

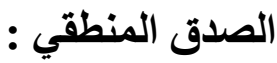

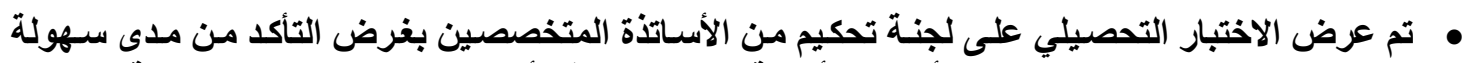

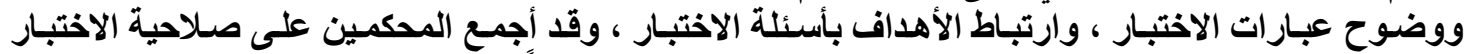
التحصيلي للتطبيق مع إبداء بعض المقار المقترحات ، وقد تم تعديل الآتي بناءاً على مقترحاتهر .

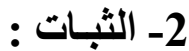

يقصد بالثبات أن يكون الاختبار منسقاً فيما يعي من النتائج ، وقد تم حساب معامل ثبات الاختبار التحصيلي

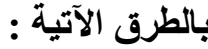

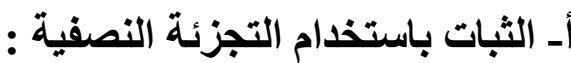

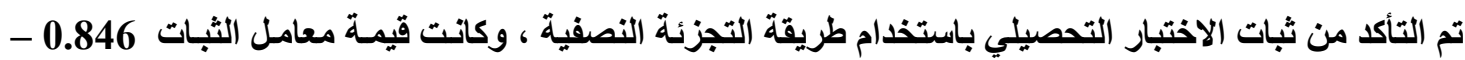

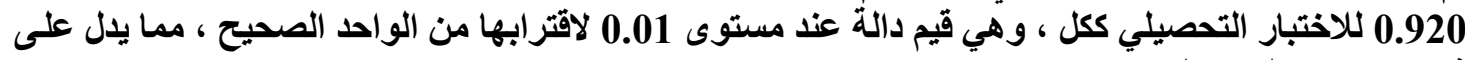
ثبات الاختبار التحصيلي.

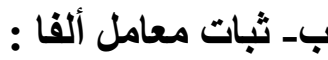

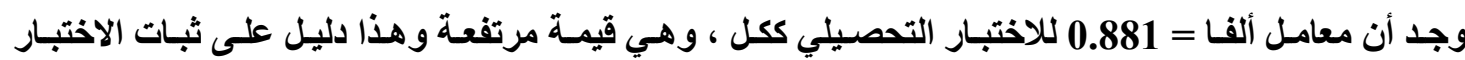
التحصيلي عند مستوى 0.01 لاقتر ابها من الواحد الصحيح .

جدول (9) ثبات الاختبار التحصيلي

\begin{tabular}{|c|c|c|c|c|}
\hline \multicolumn{2}{|c|}{ التجزئة النصفية } & \multicolumn{2}{|c|}{ معامل ألفا } & \multirow{3}{*}{ ثبات الاختبار } \\
\hline الدلالة & قيم الارتباط & الدلالة & قيم الارتباط & \\
\hline 0.01 & $0.920-0.846$ & 0.01 & 0.881 & \\
\hline
\end{tabular}

1- صدق وثبات الاختبار التطبيقى المهاري :

الصدق المنطقي : تم عرض الاختبار على مجموعة مـن الأسـاتذة المتخصصين وأقروا جميعاً بصلاحيته لانطبيق.

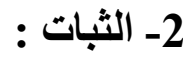

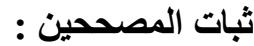

يمكن الحصول على معامل ثبات المصحصين بحساب معامل الارتباط بين الدرجات التي يعطيها مصححان أو أكثر

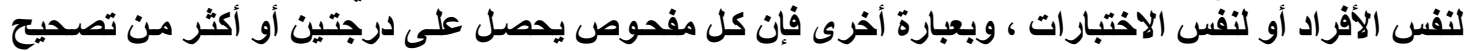

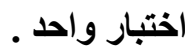
وتم التصحيح بواسطة ثلاثة من الأساتذة المحكمين وذلك باستخدام بطاقة الملاحظة في عملية التقويم وقام كل مصدح بعملية التقويم بمفرده . 


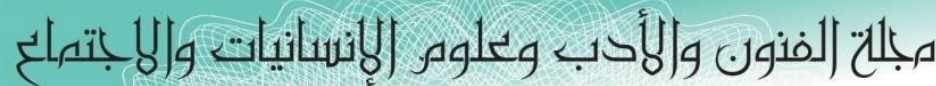
Journal of Arts, Literature, Humanities and Social Sciences

ISSN online: 2414 - 3383

ISSN print: 2616 - 3810

\section{العدد (42) أيلول - سبتهبر 2019}

وقد تم حساب معامل الارتباط بين الدرجات الثلاث التي وضعها المصحصين (س ، ص ، ع) للاختبار التطبيقي

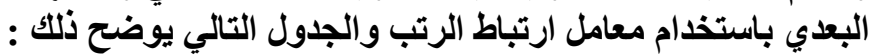

جدول (10) معامل الارتباط بين المصححين للاختبار المهاري "بطاقة الملاحظة"

\begin{tabular}{|c|c|c|c|c|c|}
\hline الملاحظة & الكُم & الأطوال & العروض & المحيطات & المصححين \\
\hline 0.741 & 0.803 & 0.916 & 0.846 & 0.712 & س ، ص \\
\hline $\begin{array}{c}\mathbf{0 . 8 3 5} \\
\end{array}$ & $\begin{array}{c}0.948 \\
\end{array}$ & 0.892 & $\begin{array}{l}0.757 \\
\end{array}$ & \begin{tabular}{c|}
0.873 \\
\end{tabular} & س ، ع \\
\hline 0.781 & 0.860 & 0.739 & 0.824 & 0.935 & ص ، ع \\
\hline
\end{tabular}

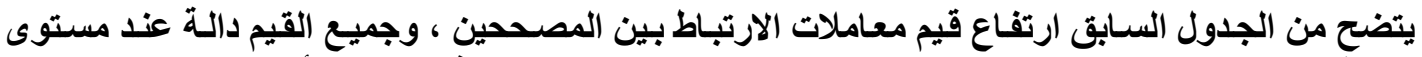
0.0101

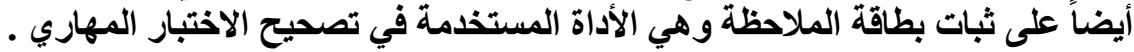

\section{نتائج البحث : النتائج الوصفية البو:}

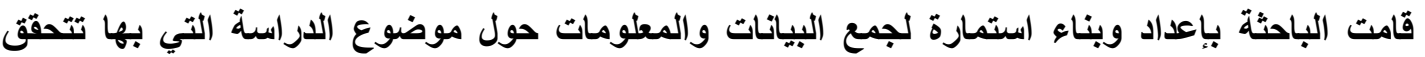

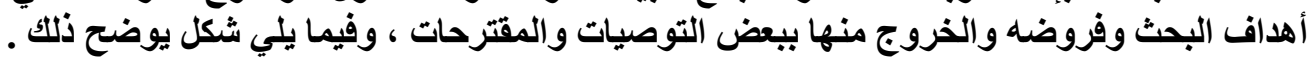

شكل (5) النتائج الوصفية

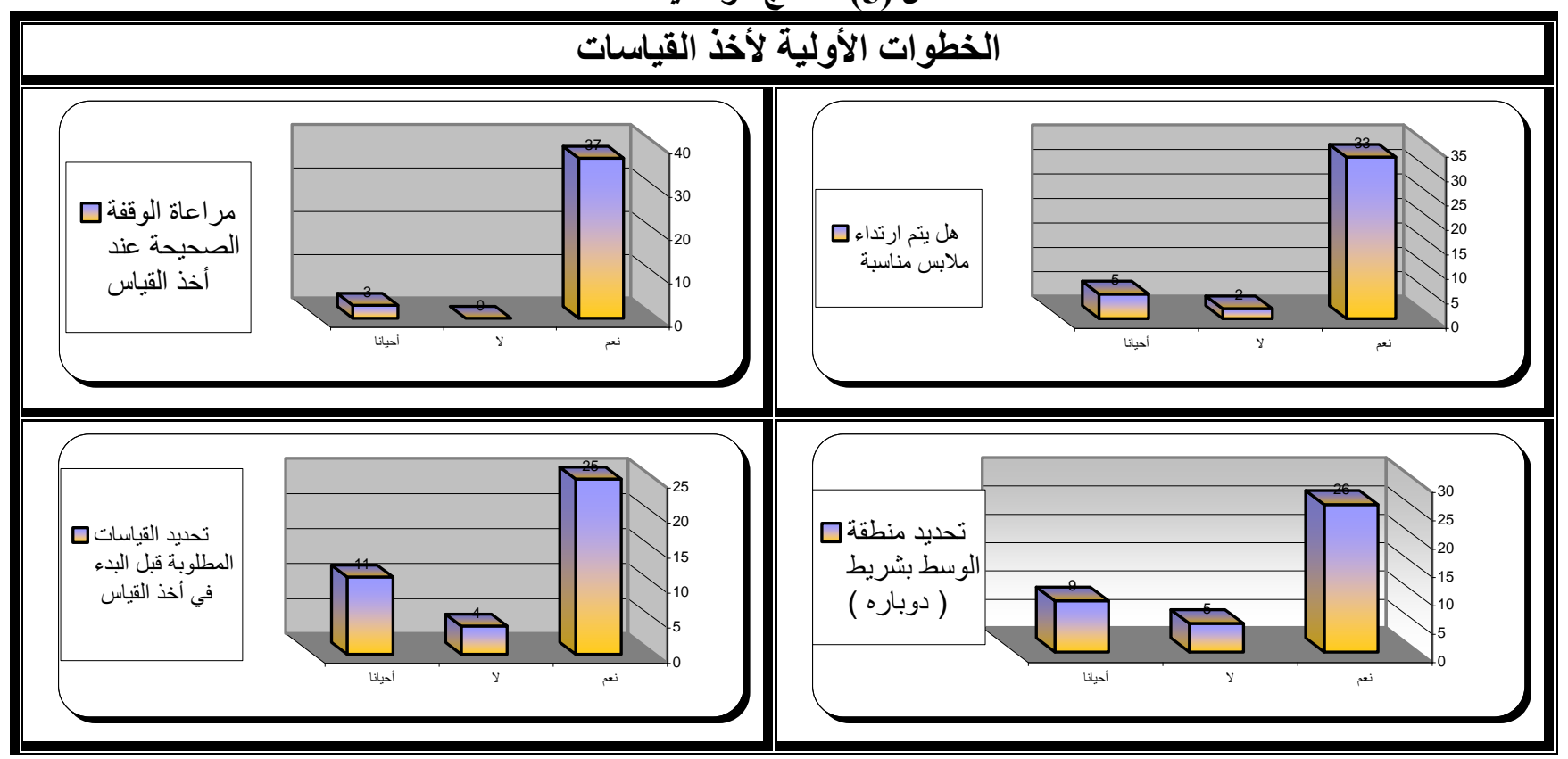




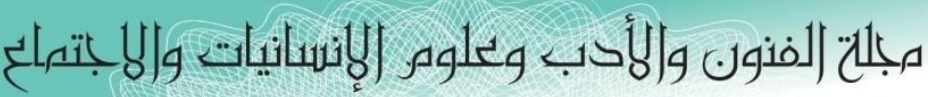
Journal of Arts, Literature, Humanities and Social Sciences

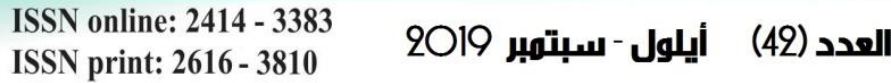

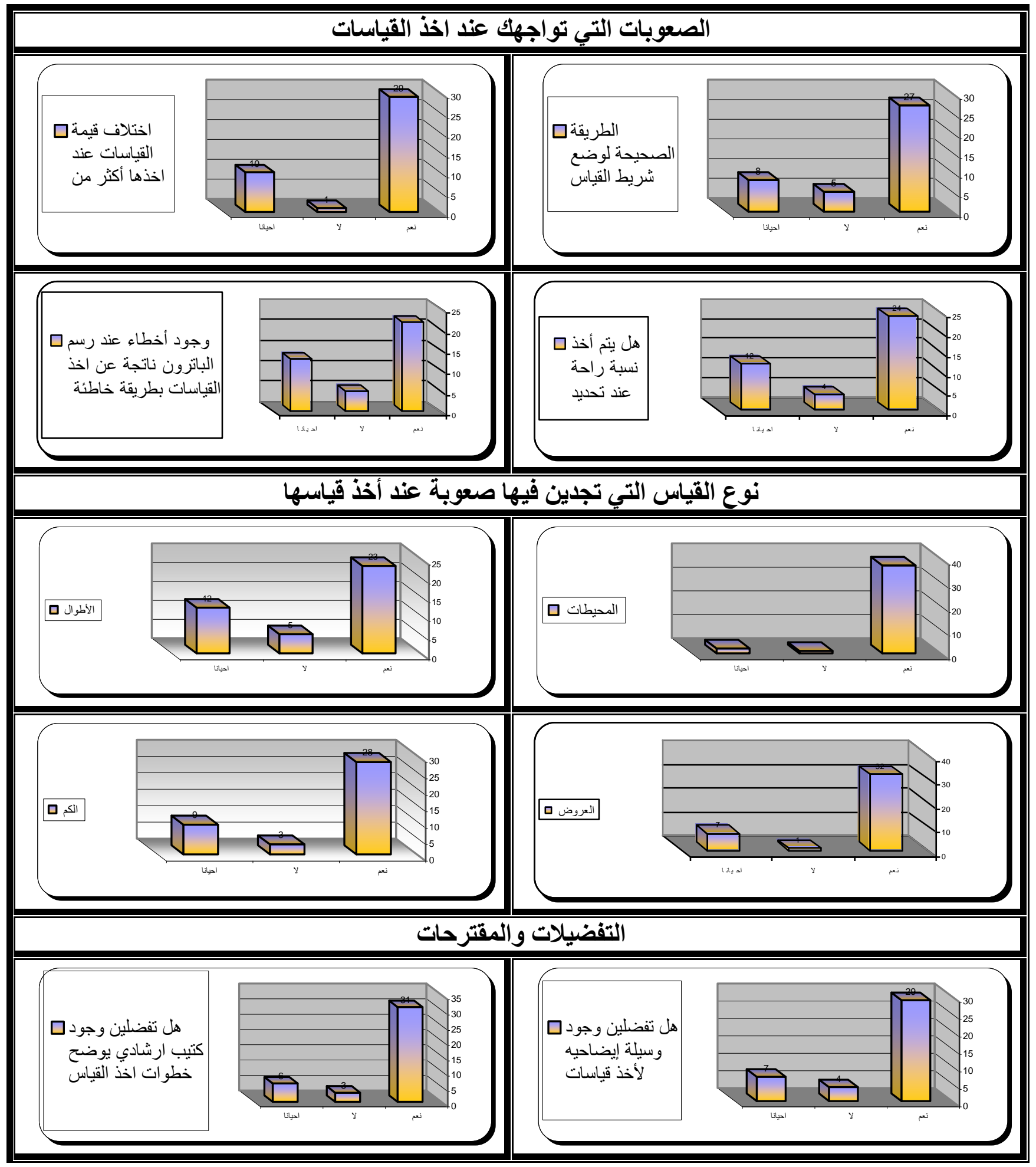




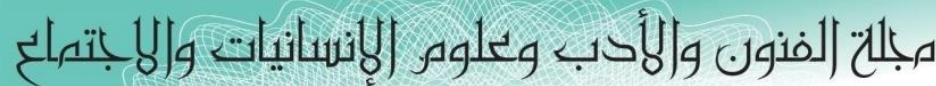

Journal of Arts, Literature, Humanities and Social Sciences

ISSN online: 2414 - 3383

ISSN print: 2616 - 3810

\section{العدد (42) أيلول - سبتهبر 2019}

¿ALLHSS

www.jalhss.com

$$
\text { النص الفرض الأول : الإئيائية : }
$$

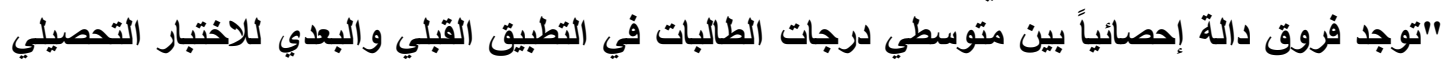

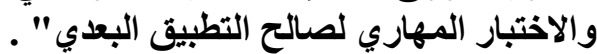

\begin{tabular}{|c|c|c|c|c|c|c|}
\hline مستوى الدلالة & قيمـة ت & "الحرجــة & 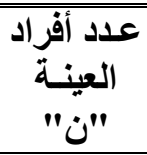 & 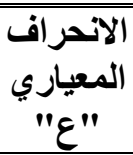 & "المتوسط & الفاعلية \\
\hline \multirow{2}{*}{$\begin{array}{c}0.01 \\
\text { لصالح البعدي }\end{array}$} & \multirow{2}{*}{42.210} & \multirow{2}{*}{39} & \multirow{2}{*}{40} & 4.921 & 45.292 & القبالـي \\
\hline & & & & 8.536 & 144.180 & البعـدي \\
\hline
\end{tabular}

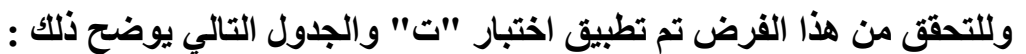

جدول (11) دلالة الفروق بين متوسطي درجات الطالبات في التطبيق القبلي والبعدي "(لفاعلية"

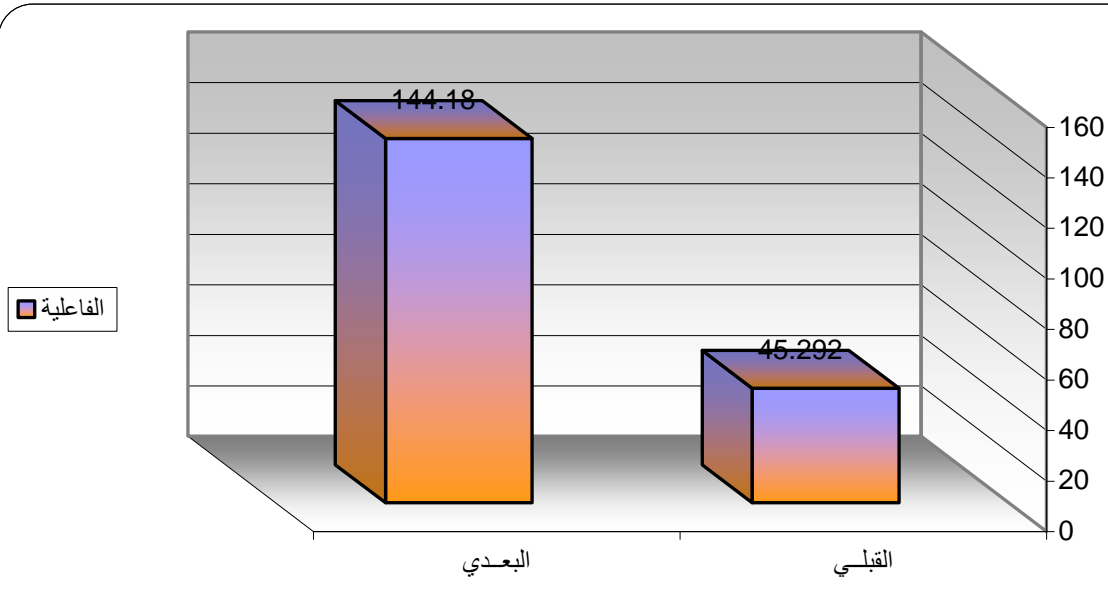

شكل (6) دلالة الفروق بين متوسطي درجات الطالبات في التطبيق القبلي والبعدي "(لفاعلية"

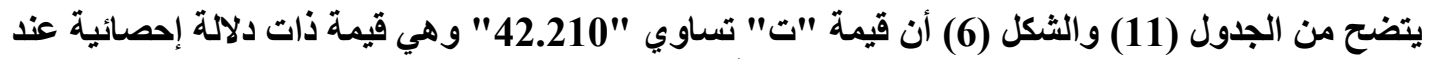

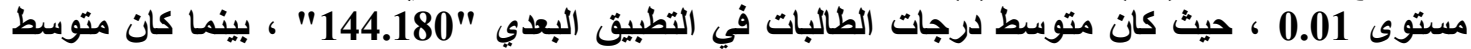
درجات الطالبات في التطبيق القبلي "45.292" ، مما يشير إلى وجود فروق حقيقية بين التطبيقين لصالح التطبيق البعدي .

ولمعرفة حجم التأثير تم تطبيق معادلة ايتا : t = قيمة (ت) = 39 = 42.210 = درجات الحرية \begin{tabular}{|c|c|c|}
\hline \multirow{2}{*}{$\mathbf{n}^{2}=$} & $\mathbf{t}^{2}$ & $\mathbf{2}$ \\
\cline { 2 - 3 } & $\mathbf{t}^{2}+\mathbf{d f}$ & $\mathbf{0 . 9 7 8}$
\end{tabular} وبحساب حجم التأثير وجد إن

$$
d=\frac{2 \sqrt{ } n^{2}}{\sqrt{1-n^{2}}}=13.31
$$




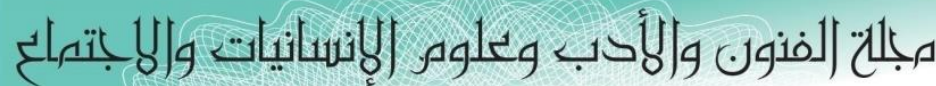

Journal of Arts, Literature, Humanities and Social Sciences

ISSN online: 2414 - 3383

ISSN print: 2616 - 3810

\section{العدد (42) أيلول - لسبتمبر 2019}

ويتحدد حجم التأثير ما إذا كان كبيراً أو متوسطاً أو صغيراً كالأتي :

$$
\begin{aligned}
& 0.2 \\
& \text { حجم تأثير صغير }=0.5 \\
& \text { حجم تأثير متوسير }=0.8
\end{aligned}
$$

وهذا يعنى أن حجم التأثير كبير ، وبذلك يتحقى الفرض الأول .

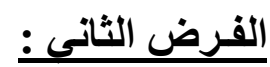

ينص الفرض الثاني على ما يلي : لئي :

"توجد فروق دالة إحصائياً بين متوسطي درجات الطالبات في التطبيق القبلي والبعدي للاختبار التحصيلي

\begin{tabular}{|c|c|c|c|c|c|c|}
\hline مستوى الدالالة & قيمة ت & "درجـات & عدد أفراد & "الانحرافياري & "المسابي & \\
\hline \multirow{2}{*}{$\begin{array}{c}0.01 \\
\text { لصالح البعدي }\end{array}$} & \multirow{2}{*}{24.035} & \multirow{2}{*}{39} & \multirow{2}{*}{40} & 1.035 & 7.022 & القبلـى \\
\hline & & & & 3.426 & 36.517 & البعـدي \\
\hline
\end{tabular}

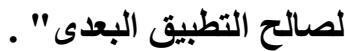

وللتحقق من صحة هذا الفرض تم تطبيق اختبار "ت" والجدول التالي يوضح ذلك :

جدول (12) دلالة الفروق بين متوسطي درجات الطالبات في التطبيق القبلي والبعدي للاختبار التحصيلي

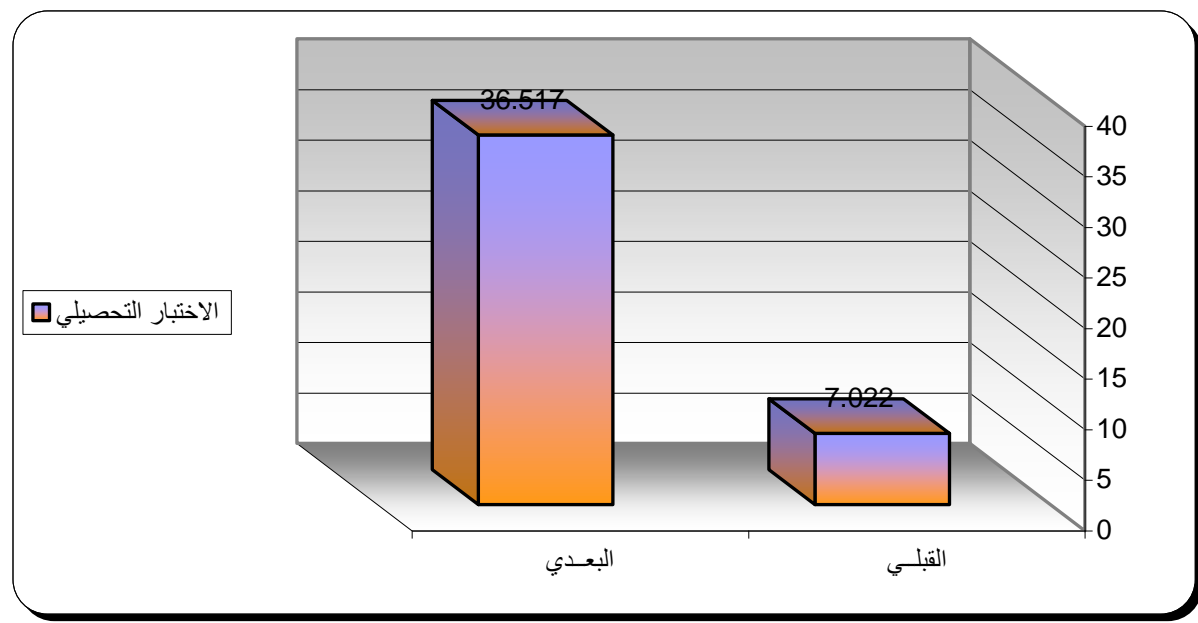

شكل (7) دلالة الفروق بين متوسطي درجات الطالبات في التطبيق القبلي والبعدي للاختبار التحصيلي

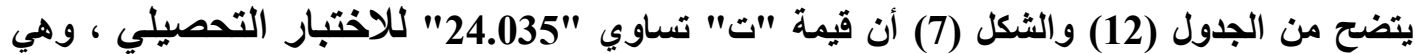

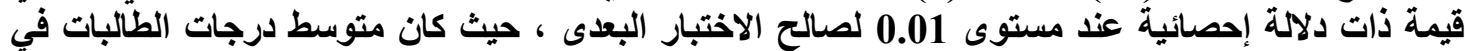
التطبيق البعدي "36.517" ، بينما كان متوسط درجات الطالبات في التطبيق القبلي "7.022" ، وبذان التلك يتحقق الفرض الثاني . 


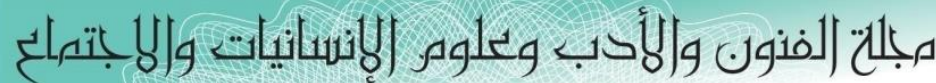

Journal of Arts, Literature, Humanities and Social Sciences

ISSN online: 2414 - 3383

ISSN print: 2616 - 3810

العدد (42) ايلول - سبتهبر 2019

$$
\begin{aligned}
& \text { الفرض الثالث : } \\
& \text { ينص الفرض الثالث على ما يلي : }
\end{aligned}
$$

"توجد فروق دالة إحصائياً بين متوسطي درجات الطالبات التبات في التطبيق القبلي والبعدي للاختبار المهاري

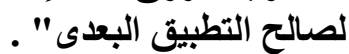
وللتحقق من صحة هذا الفرض تم تطبيق اختبار "ت" والجداول التالية توضح ذلك :

جدول (13) دلالة الفروق بين متوسطي درجات الطالبات في

\begin{tabular}{|c|c|c|c|c|c|c|}
\hline مستوى الدالادة & ق قيمة ت & "درجــــا & عداند أفراد & "المعياري & الحسابي & المحيطات \\
\hline \multicolumn{7}{|c|}{ محيط الرقبة } \\
\hline \multirow{2}{*}{ لصالج البعدي } & \multirow{2}{*}{5.005} & \multirow{2}{*}{39} & \multirow{2}{*}{40} & 0.931 & 2.220 & القبالي ي \\
\hline & & & & 1.350 & 7.635 & البعــي \\
\hline \multicolumn{7}{|c|}{ محيط الصدر } \\
\hline \multirow{2}{*}{ لصالح البعدي 0.01} & \multirow{2}{*}{4.358} & \multirow{2}{*}{39} & \multirow{2}{*}{40} & 1.673 & 2.789 & القبإي \\
\hline & & & & 1.462 & 6.914 & البعـدي \\
\hline \multicolumn{7}{|c|}{ محيط الوسط } \\
\hline \multirow{2}{*}{ لصالج البعدي } & \multirow{2}{*}{5.104} & \multirow{2}{*}{39} & \multirow{2}{*}{40} & 1.001 & 3.662 & القبالي \\
\hline & & & & 1.335 & 7.001 & البعــي \\
\hline \multicolumn{7}{|c|}{ يط الجناب } \\
\hline \multirow{2}{*}{ لصالح البعدي } & \multirow{2}{*}{6.241} & \multirow{2}{*}{39} & \multirow{2}{*}{40} & 0.924 & 1.885 & القبــي \\
\hline & & & & 1.406 & 7.523 & البعـدي \\
\hline \multicolumn{7}{|c|}{ المجموع الكلي للمحيطات } \\
\hline \multirow{2}{*}{ لصالح البعدي } & \multirow{2}{*}{15.257} & \multirow{2}{*}{39} & \multirow{2}{*}{40} & 2.670 & 10.556 & القبالي \\
\hline & & & & $\mathbf{3 . 0 3 8}$ & 29.073 & البعــي \\
\hline
\end{tabular}

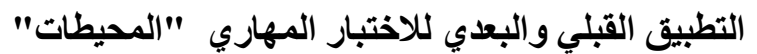


مبلح (لفنون والأدب وعلوه الانسانيات و|لبانتماع| Journal of Arts, Literature, Humanities and Social Sciences

ISSN online: 2414 - 3383

ISSN print: 2616 - 3810

العدد (42) أيلول - سبتمبر 2019

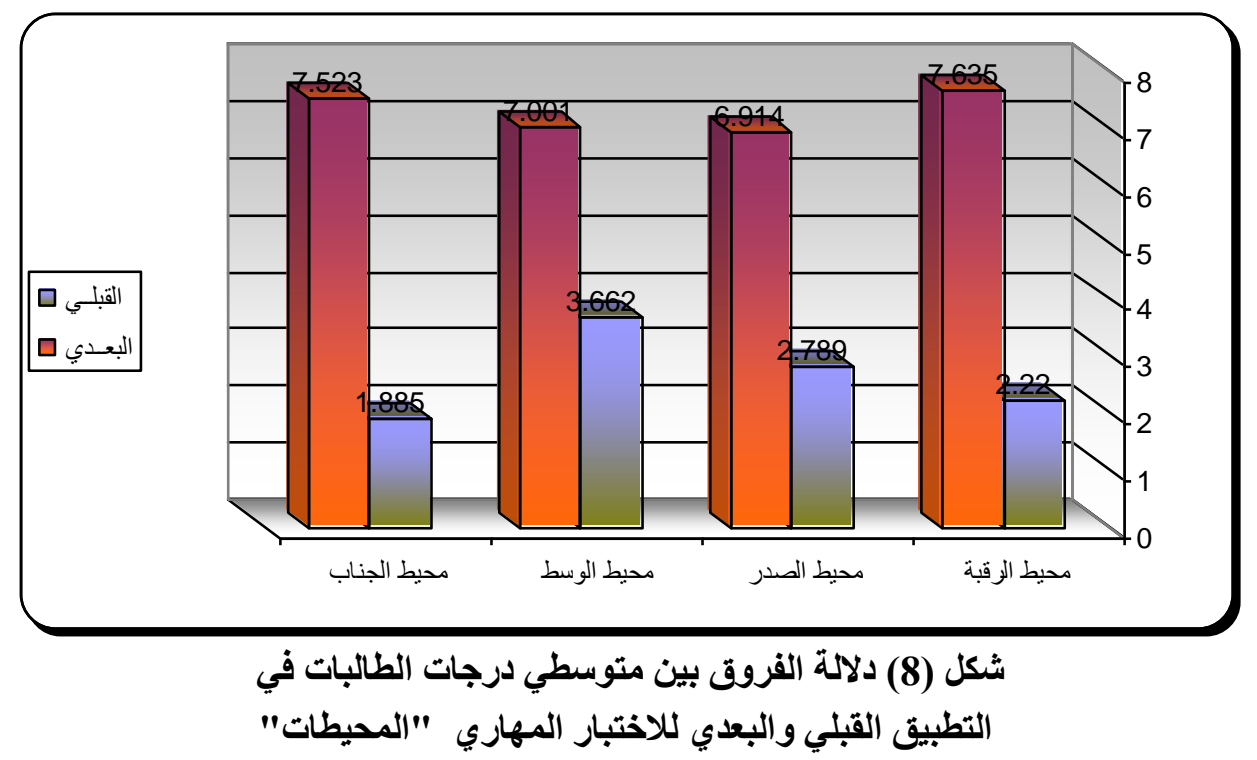

يتضح من الجدول (13) و الثكل (8) :

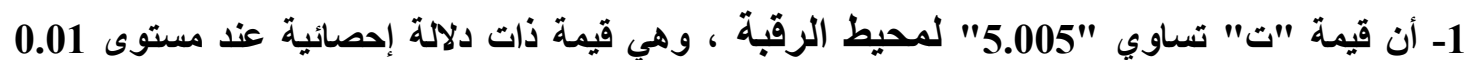
لكالح الاختبار البعدى ، حيث كان متوسط درجات الطالبات في التطبيق البعدي "7.635" ، بلئة فينما كان متوسط

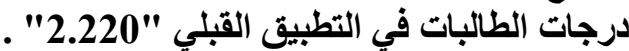

2- أن قيمة "ت" تساوي "4.358" لمحيط الصدر ، وهي قيمة ذالت ذات دلالة إحصائية عند مستوى 0.01

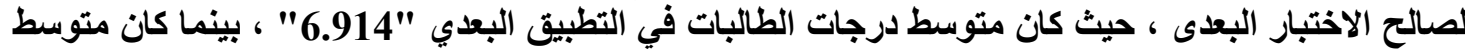

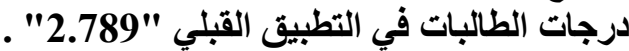

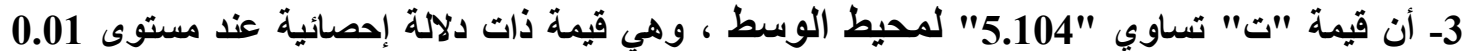

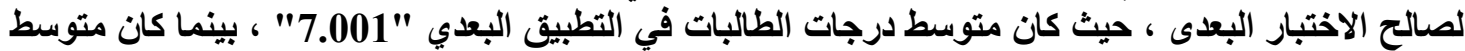

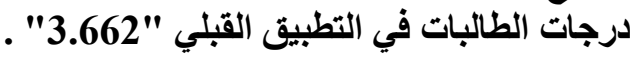

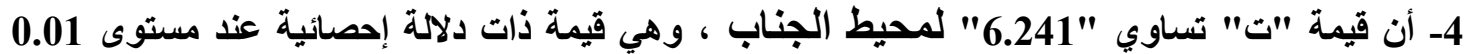

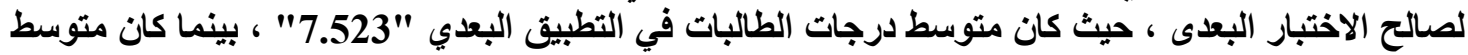

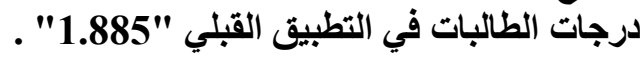

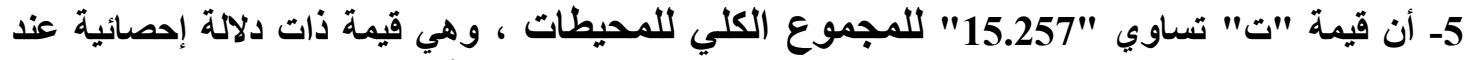

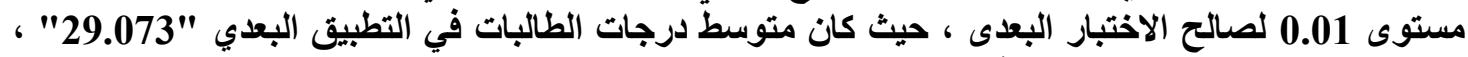

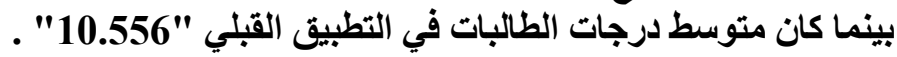




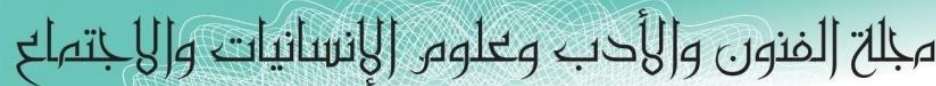

Journal of Arts, Literature, Humanities and Social Sciences

ISSN online: 2414 - 3383

ISSN print: 2616 - 3810

\section{العدد (42) أيلول - سبتهبر 2019}

جدول (14) دلالة الفروق بين متوسطي درجات الطالبات في

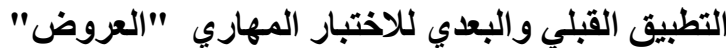

\begin{tabular}{|c|c|c|c|c|c|c|}
\hline مستوى الالالة & قيمة ت & "درجـات & عدد أفراد & الانحراف المعياري & المستوبط & العروض \\
\hline \multicolumn{7}{|c|}{ عرض الظهر } \\
\hline \multirow{2}{*}{$\begin{array}{c}0.01 \\
ل ل^{\prime}\end{array}$} & \multirow{2}{*}{4.321} & \multirow{2}{*}{39} & \multirow{2}{*}{40} & 0.787 & 2.624 & القبلـي \\
\hline & & & & 1.470 & 6.688 & البعـدي \\
\hline \multicolumn{7}{|c|}{ عرض الصدر } \\
\hline \multirow{2}{*}{ 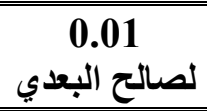 } & \multirow{2}{*}{5.823} & \multirow{2}{*}{39} & \multirow{2}{*}{40} & 1.024 & 3.001 & القبلـي \\
\hline & & & & 1.513 & 7.803 & البعـدي \\
\hline \multicolumn{7}{|c|}{ المجموع الكلي للعروض } \\
\hline \multirow{2}{*}{\begin{tabular}{|c|c|}
0.01 \\
لصالح البعدي
\end{tabular}} & \multirow{2}{*}{9.270} & \multirow{2}{*}{39} & \multirow{2}{*}{40} & 1.446 & 5.625 & القبلـي \\
\hline & & & & 2.803 & 14.491 & البعـدي \\
\hline
\end{tabular}

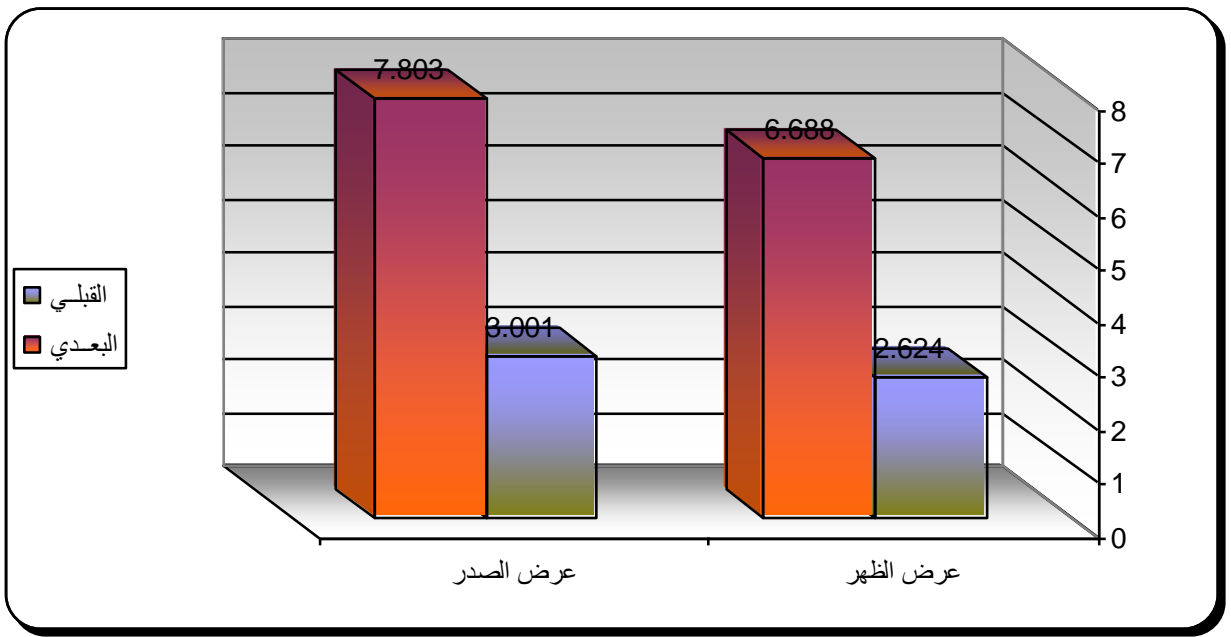

شكل (9) دلالة الفروق بين متوسطي درجات الطالبات في

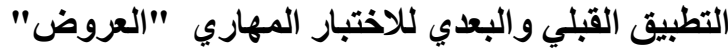

\section{يتضح من الجدول (14) و الثشكل (9) :}

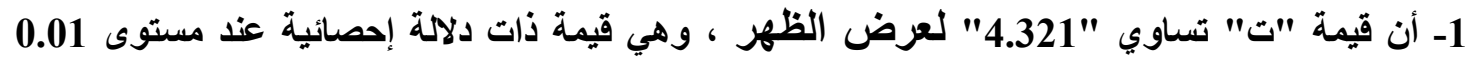

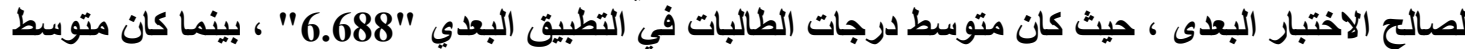

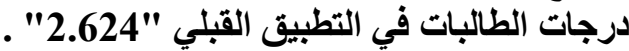

2- أن قيمة "ت" تساوي "5.823" لعرض الصدر ، و وهي قيمة ذات دلالة إحصائية عند مستوى 0.01

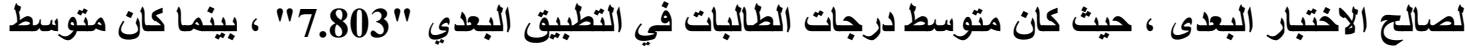
درجات الطالبات في التطبيق القبلي "3.001" مانط درجات 


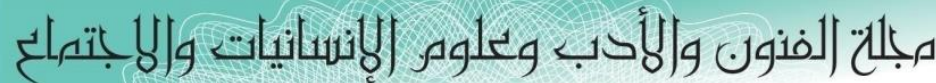

Journal of Arts, Literature, Humanities and Social Sciences

ISSN online: 2414 - 3383

ISSN print: 2616 - 3810

العدد (42) ايلول - سبتهبر 2019

3- أن قيمة "ت" تساوي "9.270" للمجموع الكلي للعروض ، وات وهي قيمة ذات دلالة إحصائية عند

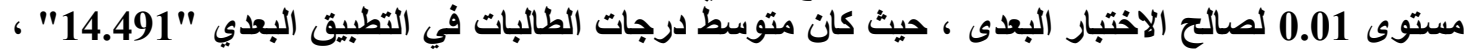
بينما كان متوسط درجات الطالبات في التطبيق القبلي "5.625" مئوس درجات

جدول (15) دلالة الفروق بين متوسطي درجات الطالبات في

التطبيق القبلي والبعدي للاختبار المهاري " الأطوال

\begin{tabular}{|c|c|c|c|c|c|c|}
\hline مستوى الدلالة & قيمة ت & "درجـات & عدد أفراد & "الانحراف & "المستبط & الأطوال \\
\hline \multicolumn{7}{|c|}{ طول الظهر } \\
\hline \multirow{2}{*}{$\begin{array}{c}0.01 \\
\text { لصالح البعدي } \\
\end{array}$} & \multirow{2}{*}{6.027} & \multirow{2}{*}{39} & \multirow{2}{*}{40} & 1.424 & 3.620 & القبلـي \\
\hline & & & & 1.735 & 7.992 & البعـدي \\
\hline \multicolumn{7}{|c|}{ طول الصدر } \\
\hline \multirow{2}{*}{ لصالح البعدي } & \multirow{2}{*}{4.442} & \multirow{2}{*}{39} & \multirow{2}{*}{40} & 0.883 & 2.014 & القبلـي \\
\hline & & & & 1.110 & 5.841 & البعـدي \\
\hline \multicolumn{7}{|c|}{ طول الجنب } \\
\hline \multirow{2}{*}{ لصالح البعدي } & \multirow{2}{*}{5.938} & \multirow{2}{*}{39} & \multirow{2}{*}{40} & 0.537 & 2.558 & القبلـي \\
\hline & & & & 1.293 & 6.705 & البعـدي \\
\hline \multicolumn{7}{|c|}{ طول الكتف } \\
\hline \multirow{2}{*}{$\begin{array}{c}0.01 \\
ل ل^{\prime} \\
\end{array}$} & \multirow{2}{*}{6.324} & \multirow{2}{*}{39} & \multirow{2}{*}{40} & 1.101 & 2.994 & القبالـي \\
\hline & & & & 2.035 & 7.610 & البعـدي \\
\hline \multicolumn{7}{|c|}{ طول الحجر } \\
\hline \multirow{2}{*}{ 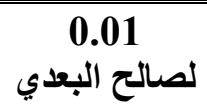 } & \multirow{2}{*}{7.112} & \multirow{2}{*}{39} & \multirow{2}{*}{40} & $\mathbf{0 . 5 8 7}$ & 1.768 & القبالبي \\
\hline & & & & 1.444 & 6.222 & البعـدي \\
\hline \multicolumn{7}{|c|}{ الطول الكلي } \\
\hline \multirow{2}{*}{ لصالح البعدي } & \multirow{2}{*}{5.083} & \multirow{2}{*}{39} & \multirow{2}{*}{40} & 0.883 & 2.001 & القبلـي \\
\hline & & & & 1.240 & 6.546 & البعـدي \\
\hline \multicolumn{7}{|c|}{ المجموع الكلي للأطوال } \\
\hline \multirow{2}{*}{ 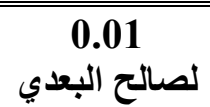 } & \multirow{2}{*}{21.309} & \multirow{2}{*}{39} & \multirow{2}{*}{40} & 1.813 & 14.955 & القبالـي \\
\hline & & & & 3.745 & $4 \mathbf{4 0 . 9 1 6}$ & البعـدي \\
\hline
\end{tabular}




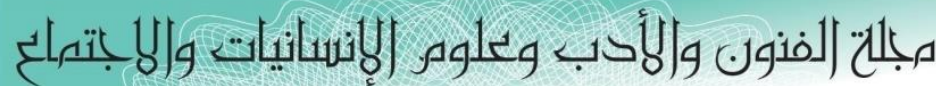
Journal of Arts, Literature, Humanities and Social Sciences

ISSN online: 2414 - 3383

ISSN print: 2616 - 3810 العدد (42) أيلول - سبتمبر 2019

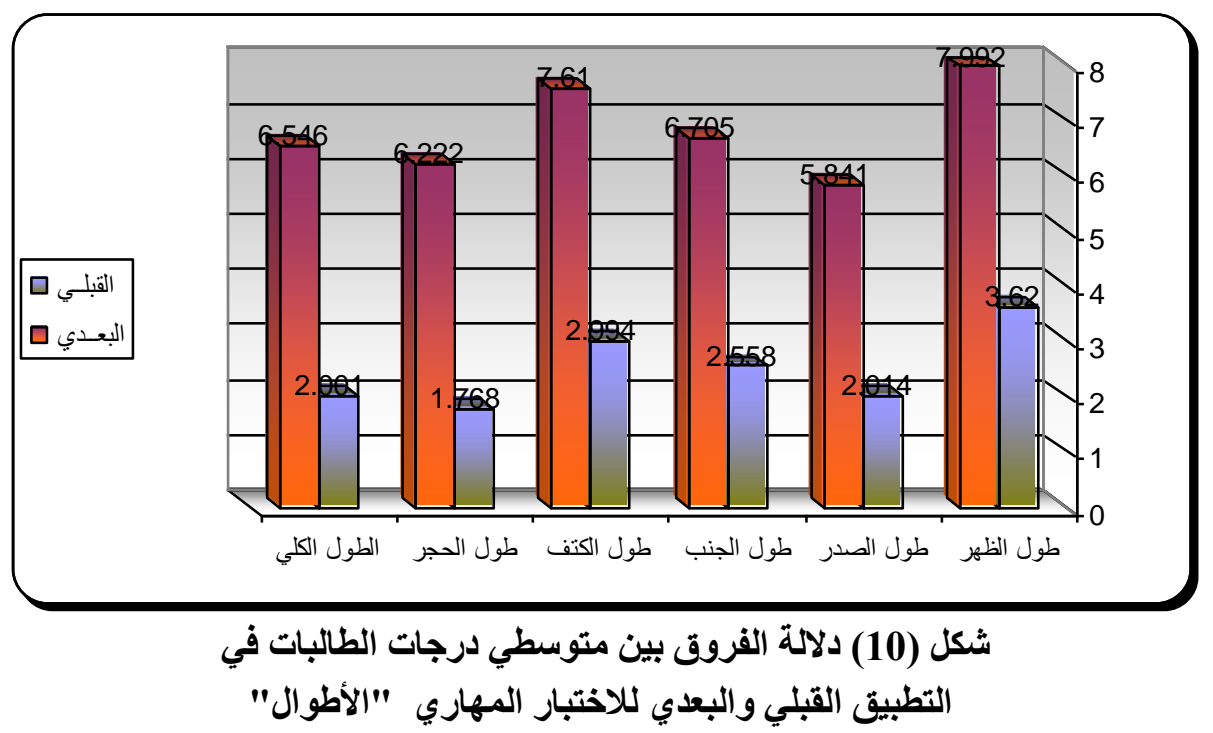

يتضح من الجدول (15) والثكل (10) :

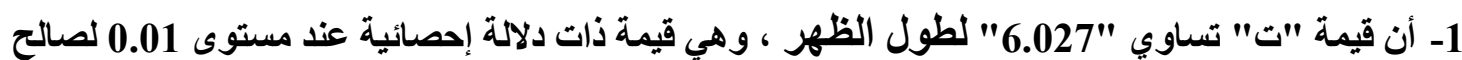
الاختبار البعدى ، حيث كان متوسط درجات الطالبات في التطبيق البعدي "7.992" ، بلتئ ، بينما كان متوسط درجات

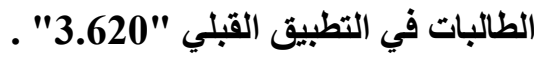

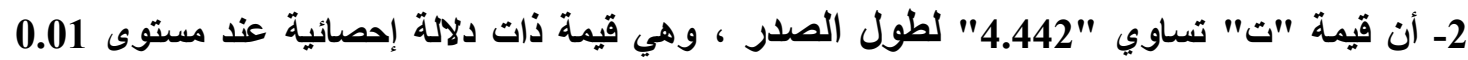

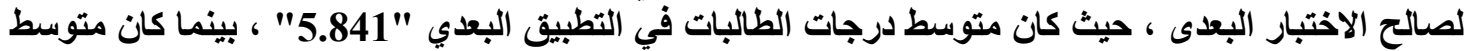

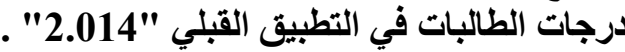

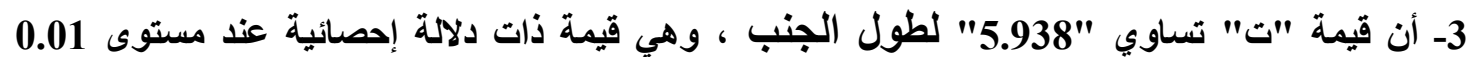

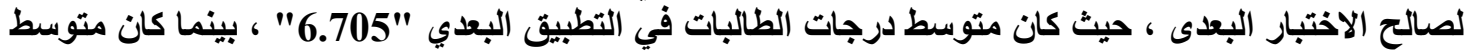

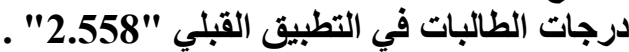

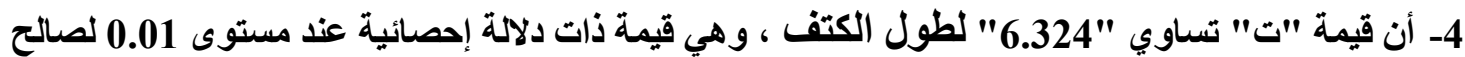

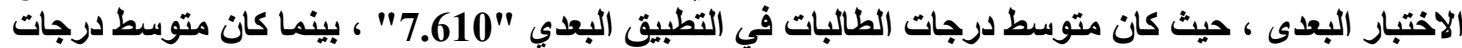

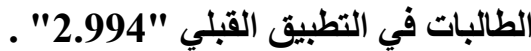

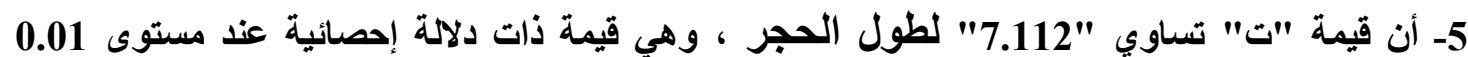

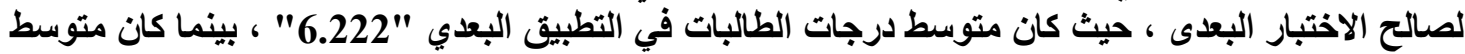

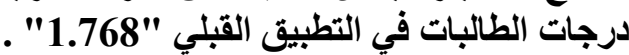

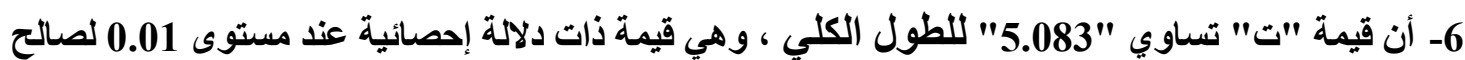

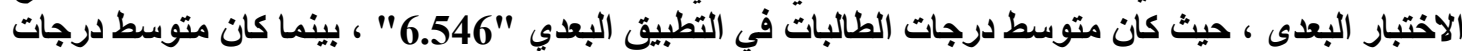

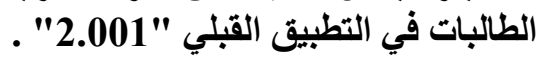
7- أن قيمة "ت" تساوي "21.309" للمجموع الكلي للأطوال ، وهي قيمة ذات دلاتلاتلة إحصائية عند مستوى 0.01 لصالح الاختبار البعدى ، حيث كان متوسط درجات الطالبات في التطبيق البعدي "14.95 "40.916" ، بينما كان متوسط درجات الطالبات في التطبيق القبلي "14.955" . 
مبلح (لفنون والأدب وعلوه الانسانيات و|لبانتماع| Journal of Arts, Literature, Humanities and Social Sciences

ISSN online: 2414 - 3383

ISSN print: 2616 - 3810 العدد (42) ايلول -سبتهبر 2019

$$
\text { جدول (16) دلالة الفروق بين متوسطي درجات الطالبات في }
$$

التطبيق القبلي والبعدي للاختبار المهاري "الكم" دئل

\begin{tabular}{|c|c|c|c|c|c|c|}
\hline مستوى الدلالة & قيمة ت & "درجـات & عدان أفزراد & "الاتحراف & الحستبط المسي & الكم \\
\hline \multicolumn{7}{|c|}{ محيط الذراع } \\
\hline \multirow{2}{*}{ 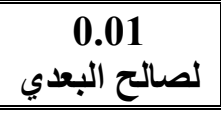 } & \multirow{2}{*}{8.442} & \multirow{2}{*}{39} & \multirow{2}{*}{40} & (0.733 & 1.605 & القبالـي \\
\hline & & & & 2.510 & 7.772 & البعـدي \\
\hline \multicolumn{7}{|c|}{ طول الكم } \\
\hline \multirow{2}{*}{ 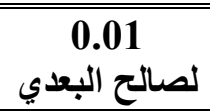 } & \multirow{2}{*}{4.220} & \multirow{2}{*}{39} & \multirow{2}{*}{40} & 1.068 & 3.442 & القبالـي \\
\hline & & & & 2.033 & 7.521 & البعـدي \\
\hline \multicolumn{7}{|c|}{ محيط الإسورة } \\
\hline \multirow{2}{*}{$\begin{array}{c}0.01 \\
ل ل^{\prime}\end{array}$} & \multirow{2}{*}{6.326} & \multirow{2}{*}{39} & \multirow{2}{*}{40} & \begin{tabular}{c|}
$\mathbf{0 . 7 7 3}$ \\
\end{tabular} & 2.087 & القبالـي \\
\hline & & & & 1.991 & 7.890 & البعـدي \\
\hline \multicolumn{7}{|c|}{ المجموع الكلي للكم } \\
\hline \multirow{2}{*}{ 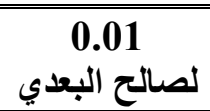 } & \multirow{2}{*}{12.204} & \multirow{2}{*}{39} & \multirow{2}{*}{40} & 1.327 & 7.134 & القبلـي \\
\hline & & & & 2.556 & 23.183 & البعـدي \\
\hline
\end{tabular}

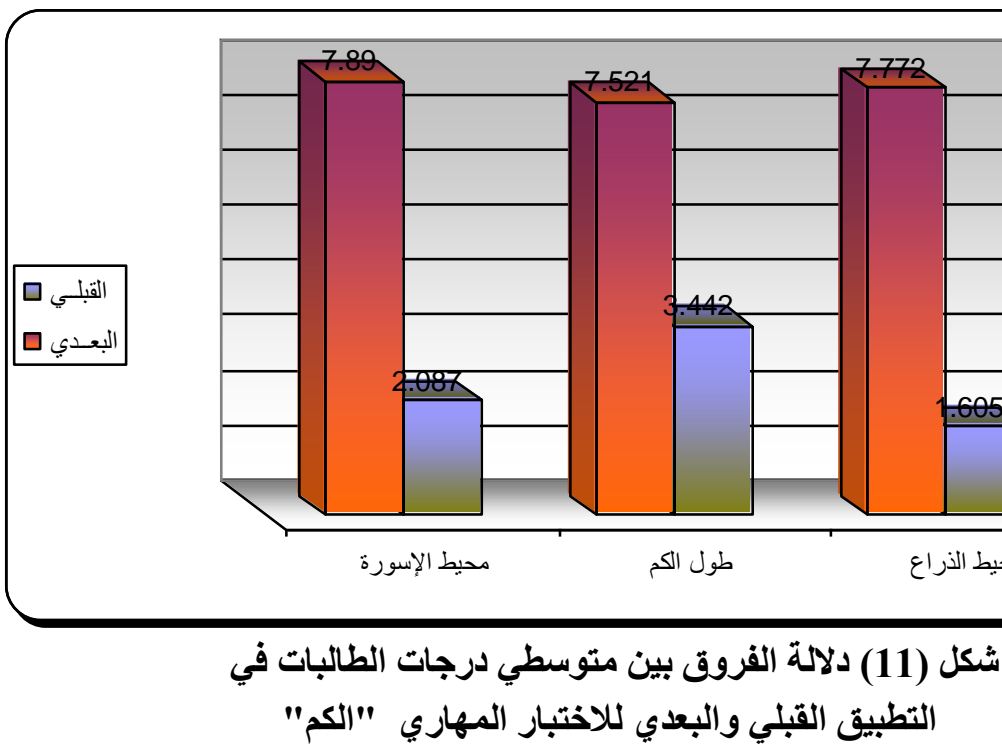

يتضح من الجدول (16) و الثكل (11) :

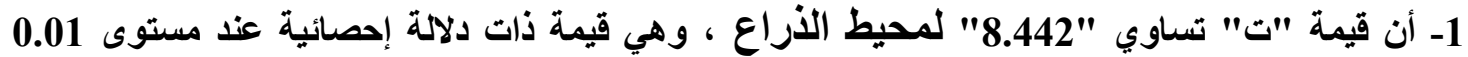

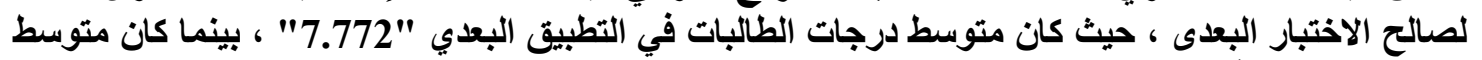

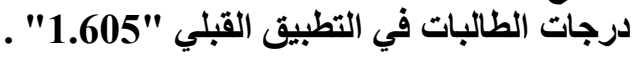




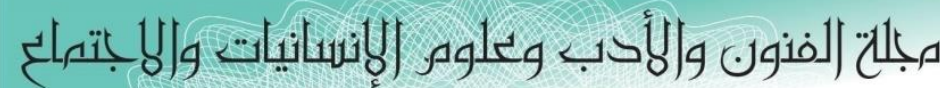
Journal of Arts, Literature, Humanities and Social Sciences

ISSN online: 2414 - 3383

ISSN print: 2616 - 3810

\section{العدد (42) أيلول - سبتمبر 2019}

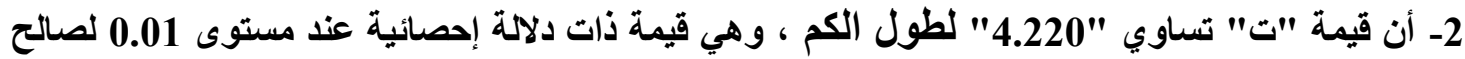

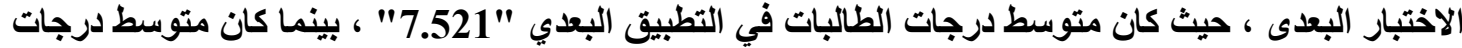

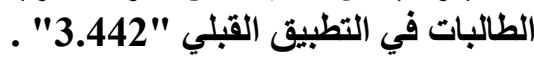

3- أن قيمة "ت" تساوي "6.326" لمحيط الإسورة ، ، وهي قيمة ذات دلالة إحصائية عند مستوى 0.01

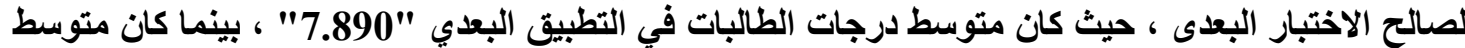
درجات الطالبات في التطبيق القبلي "2.087" دان متون

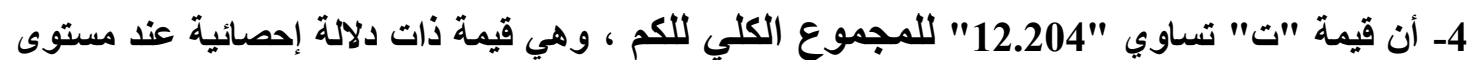

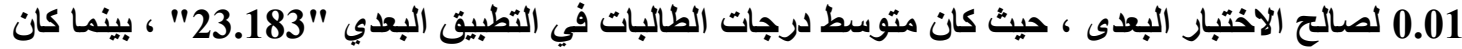

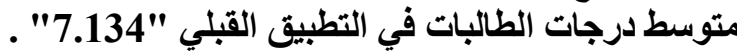

جدول (17) دلالة الفروق بين متوسطي درجات الطالبات في

التطبيق القبلي والبعدي للمجموع الكلي للاختبار المهاري

\begin{tabular}{|c|c|c|c|c|c|c|}
\hline مستوى الدالالة & قيمة ت & "درجــات & "العدينة أفراد & "الانحرافياري & الحستوسطي & المهاري ككل الاختبار \\
\hline \multirow{2}{*}{ لصالح البعدي } & \multirow{2}{*}{39.762} & \multirow{2}{*}{39} & \multirow{2}{*}{40} & 3.552 & 38.270 & القبالي \\
\hline & & & & 6.493 & $\mathbf{1 0 7 . 6 6 3}$ & البعــدي \\
\hline
\end{tabular}

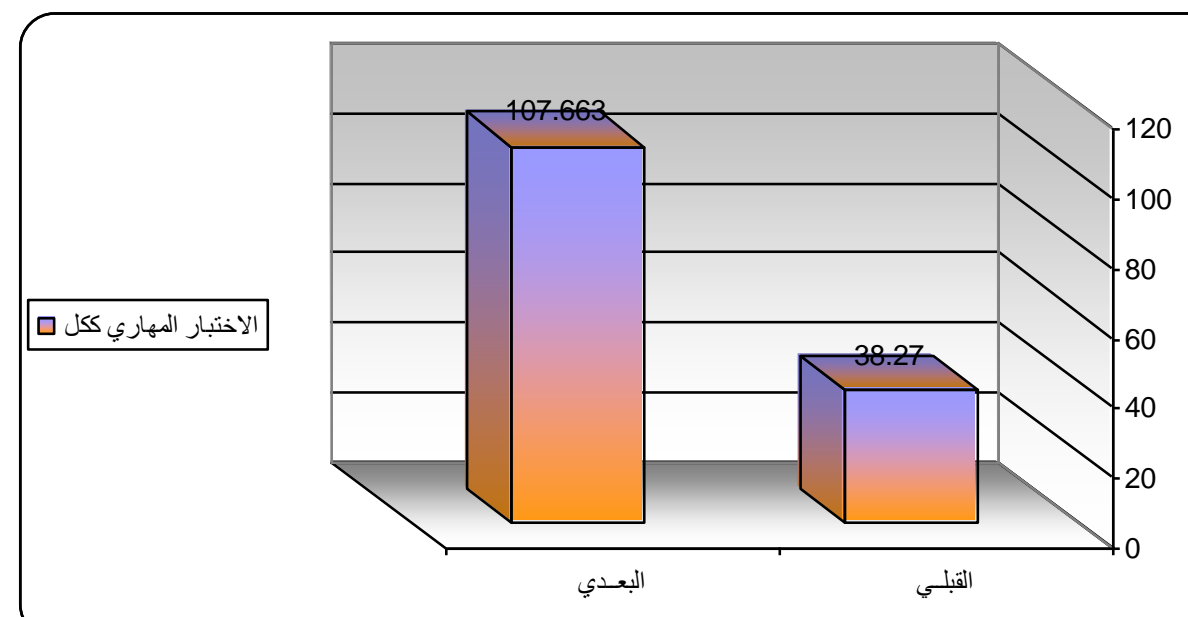

شكل (12) دلالة الفروق بين متوسطي درجات الطالبات في

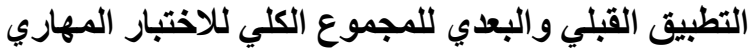

يتضح من الجدول (17) والثكل (12) أن قيمة "ت" تساوي "39.762" للمجموع الكلي للاختبار

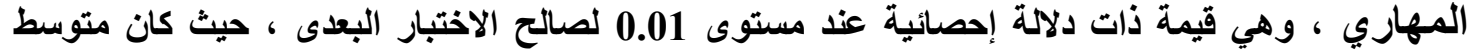
درجات الطالبات في التطبيق البعدي "107.663" ، بينما كان متوسط درجات الطالبات في التطبيق القبلي التوان "38.270" ، وبذلك يتحقق الفرض البطي الثالث . التوصيات : 1 التيات 1- الاهتمام بالبحث وعلى ما يحتويه من معلومات في دراسة اخذ القياسات بالطريقة الصحيحة . 


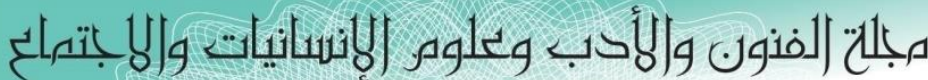

Journal of Arts, Literature, Humanities and Social Sciences

ISSN online: 2414 - 3383

ISSN print: 2616 - 3810

\section{العدد (42) أيلول - سبتهبر 2019}

2- اعتماد هذا البحث في مكتبة كلية التصاميم لطالبات قسم الملابس والنسيج .

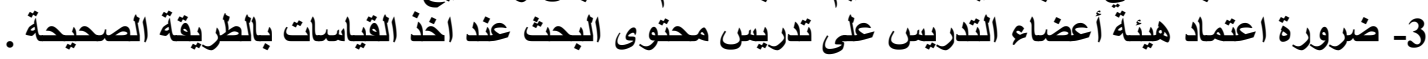

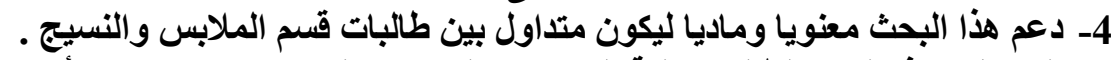
5- التعريف بهذا البحث لطالبات كلية الملابس والنيات ولنسيج وكل من تهتم بتصميم الأزياء .

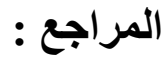

، ، (1956م) : طريقة التفصيل بروفيلي الجزء الثاني ، القاهرة ، مطابع دار المعارف. $-1$

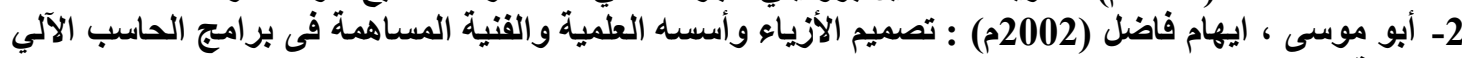

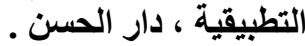
3- أل سعود ، سلطان بن عبد العزيز ( هوبن 199 م ) ) : الموسوعة العربية العالمية ، الرباط ، دار النشر ، مؤسس

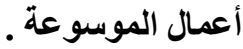

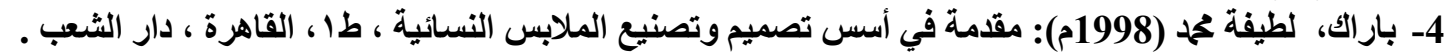

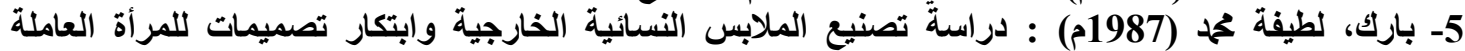

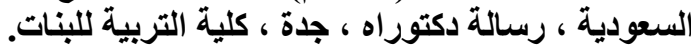

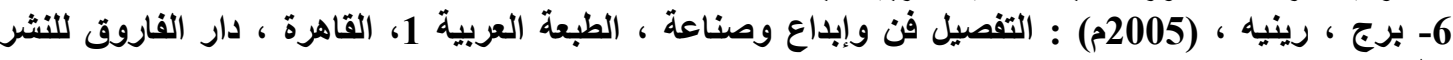

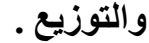

7- بروفيلي، ج (1949م) : طريقة بروفيلي الجزء الأول ، القاهرة ، مطبعة شندلر العربية .

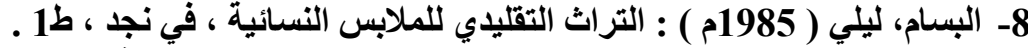

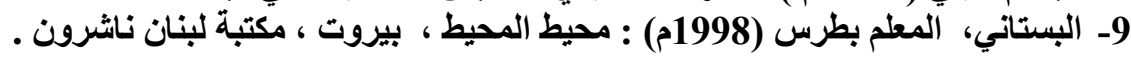

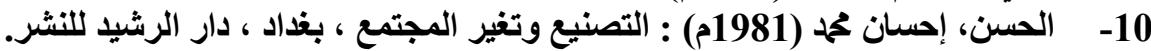

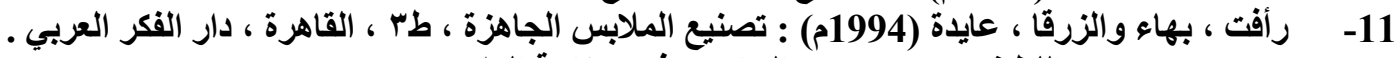

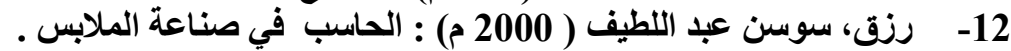

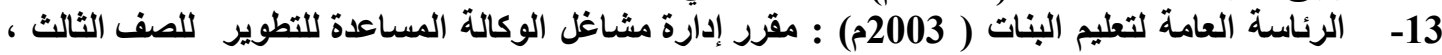

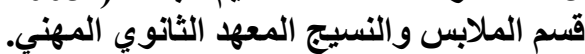
14- الزفتاوي، حنان نبية وعبود، دعاء لمحما (2003م) : التقنيات الحديثة في إعداد المانيكان للتثكيل ، ط1 ،

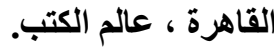

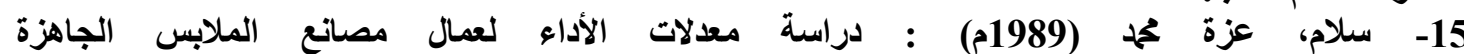

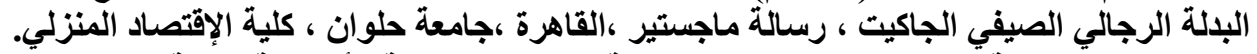

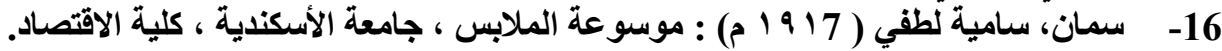

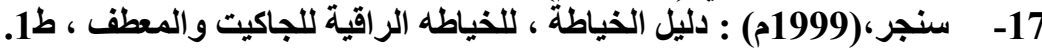

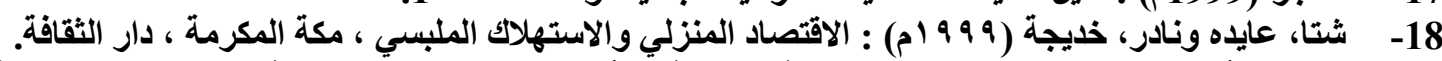

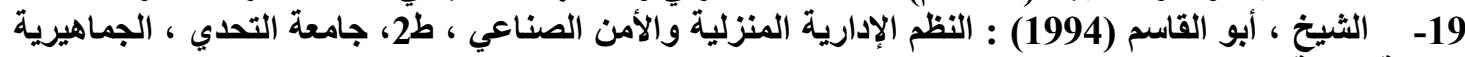
العربية الليبية.

20-

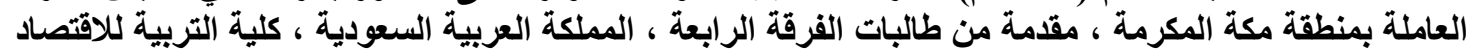

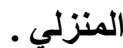

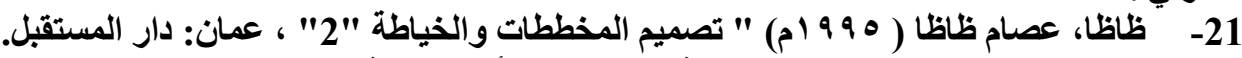

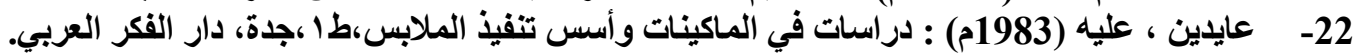

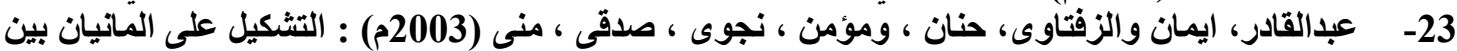

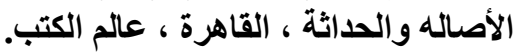

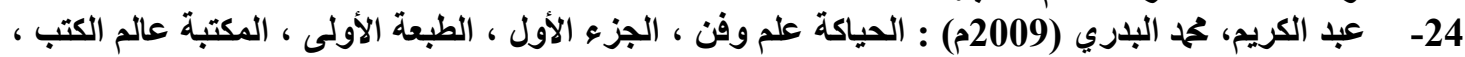

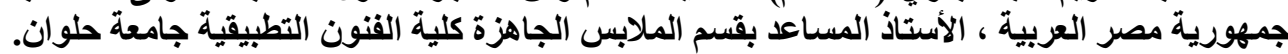

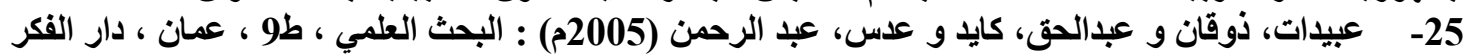

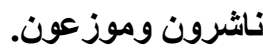




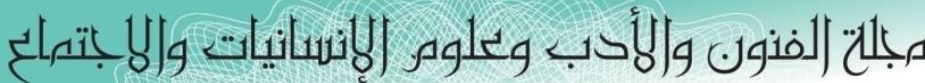

Journal of Arts, Literature, Humanities and Social Sciences

ISSN online: 2414 - 3383

ISSN print: 2616 - 3810

\section{العدد (42) ايلول - سبتمبر 2019}

26- عنان ، محمود عبدا لفتاح وباهي، مصطفى حسين (2005م) ، البحث العلمي ، القاهرة ، الدار العالمية ل تلنشر والتوزيع.

27- عيد، رشدي علي (2000م) : العوامل المؤثرة في تقييم جودة الملابس الجاهزة ، مجلة الاقتصاد المنزلي ،

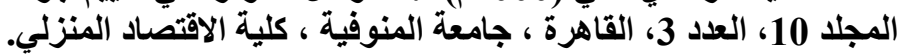

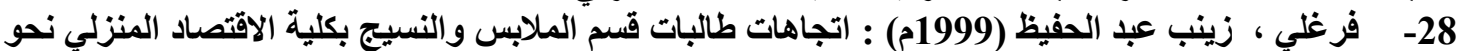

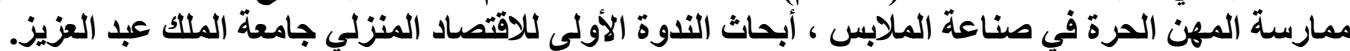

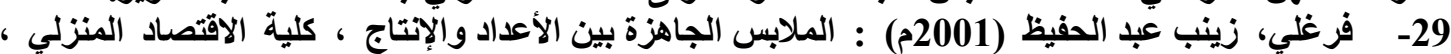

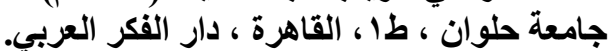

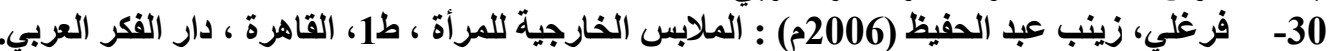

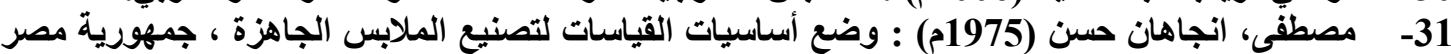

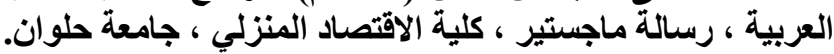

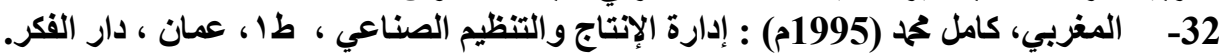

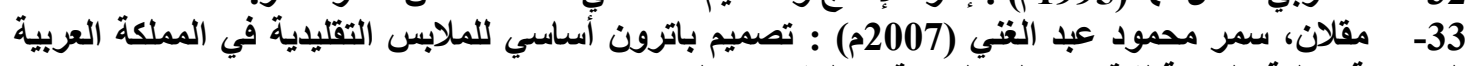

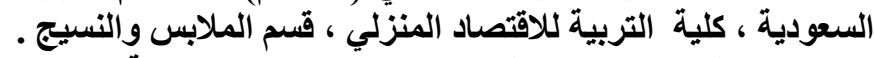

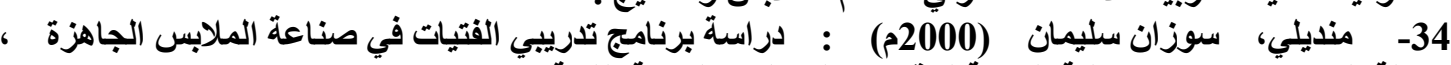

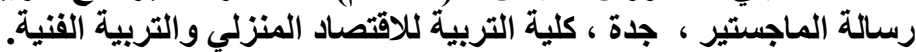

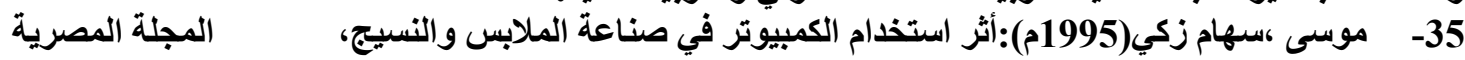

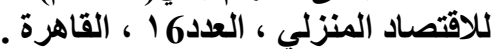

36- موسى ، سلهام زكي (1995م) : آثر استخدام الكومبيوتر في صناعة الملابس والنسيج ، المجلة المصرية

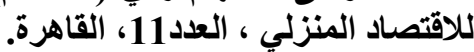

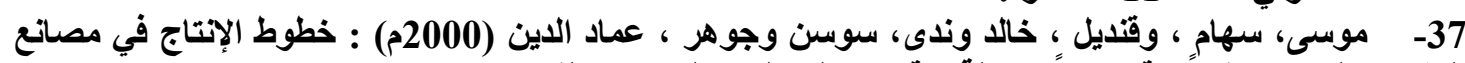

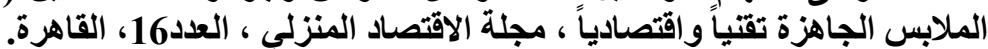

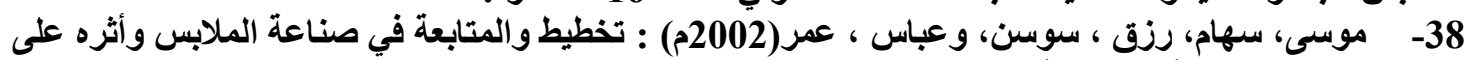

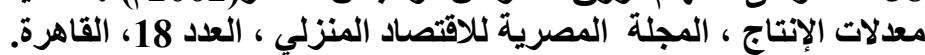

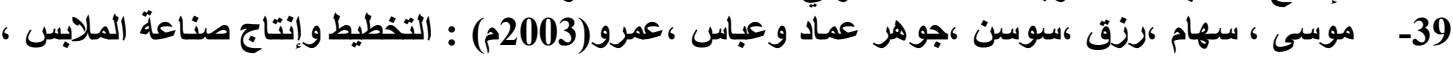

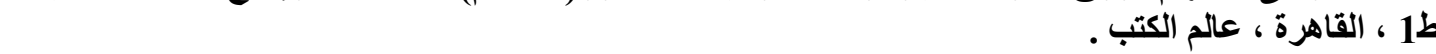

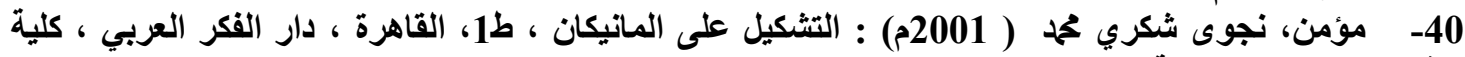

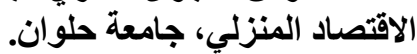

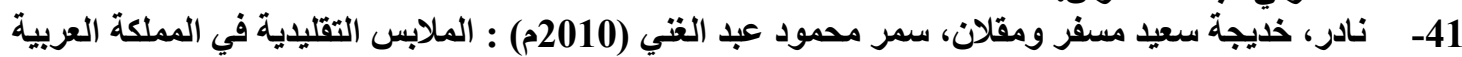

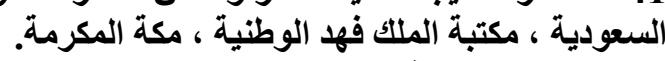

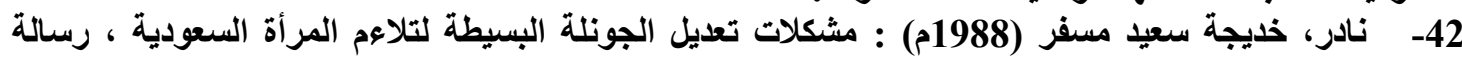
ماجستير، كلية التربية للاقتصاد المنزلي، مكة المكرمة.

43- Erwin,D.Mabel\&Kinchen,A.Lila,(1974):"Clothing For Modern",The Macmillan publishing, New York.

44- King, Kenneth,(2002):"Te basic Sleeve ",CD Book, U.S.A.

45- published by Hp Books, (1983):"Sewing The Complete Guide",Hp Books, U.S.A.

46- https://ar.m.wikipedia.org/wiki

47- Huttan.cunning Com.

48- www.taunton.com/pages/t00004.asp 